\title{
Possibilities of Limiting the Protection of Large-Scale Investments in Farmland
}

\author{
Zoe Cometti* (i)
}

(Accepted 26 January 2020)

\begin{abstract}
Large-scale investments in farmland can generate adverse effects on food security, minority groups, and the environment. Consequently, this Article analyzes to what extent international investment law has the potential to prevent those effects, considering the current investment treaty reform towards a symmetrical mechanism promoting sustainable development. First this Article presents the current substantive standard on expropriation of large-scale investments in farmland and the regulatory space left for host states. This Article then frames a potential public interest clause that would have the effect of granting due protection to investors and the right to regulate to host states, while not undermining the public interest and also preventing the adverse effects of these investments.
\end{abstract}

Keywords: Large-scale investments; public interest; investor-state dispute settlement; expropriation; international investment law

\section{A. Introduction}

In the last decade, large-scale investments in farmland received significant attention from scholars, civil society, United Nations specialized agencies such as the Food and Agriculture Organization (FAO), and the World Bank Group (WBG). Even though these investments are promoted to improve the development of low and middle-income countries, they may provoke far-reaching adverse impacts on host states' populations, the environment, and development. Therefore, it is not surprising that in the academic field, authors usually refer to such investments as land grabbing or land grabs. Especially concerned by these investments are indigenous communities and rural farmers. As these investments are promoted, as well as criticized, this Article tries to evaluate how and to what extent international investment law is suited to solve eventual investment disputes related to large-scale investments in farmland.

Both international investment law and large-scale investments in farmland are sharply criticized by civil society and scholars alike. This Article brings these two topics together and explains how they relate to each other. This approach allows us to understand the current reform of investment treaties and evaluate where, and if, the reform concerns such investments. In this context, the concerns on large-scale investments in farmland, together with criticisms on international investment law and its ISDS mechanism, are tracked and evaluated. This Article discusses the

${ }^{\star}$ The author holds a MLaw from University of Fribourg, a Master in International Law, Investment and Trade from Universidad de Chile and a LL.M.int from Ruprecht-Karls-Universität Heidelberg. This Article is based on the author's LL.M. thesis. The author is grateful to Professor Andrea Ernst (thesis supervisor) for precious comments on previous drafts. She thanks the anonymous reviewers and the editorial team of the German Law Journal for helpful comments on earlier versions of this Article.

(c) The Author(s), 2020. Published by Cambridge University Press on behalf of the German Law Journal. This is an Open Access article, distributed under the terms of the Creative Commons Attribution licence (http://creativecommons.org/licenses/by/4.0/), which permits unrestricted re-use, distribution, and reproduction in any medium, provided the original work is properly cited. 
current reform and argues that the asymmetrical conception of international investment law should be switched to a symmetrical one. Therefore, considering the current reform of investment treaties towards a symmetrical conception of the branch, a public interest clause should be framed to prevent the generation of adverse impacts of large-scale investments in farmland.

This Article is divided into three parts, followed by concluding remarks. Section B presents the peculiarities of large-scale investments in farmland and the main characteristics of the so-called land grabbing. Once the investment is defined, its protection and promotion are analyzed under international investment law-all while considering the recent development of this branch of law. This Article pays attention to the role of the investor and the protection of the investor's investments. In contrast, Section $\mathrm{C}$ deals with the role of the states, or rather, the host states, concerning large-scale investments in farmland and their right to regulate. In addition, this Article also addresses the new developments in ISDS mechanism and investment treaty reform. Section $\mathrm{D}$ focuses on framing a public interest clause conceived as a provision that could be introduced in an investment treaty to limit and prevent the adverse effects of large-scale investments in farmland and foster investments that are compatible with sustainable development.

Succinctly put, Section B focuses on the general substantive standards that host states shall grant to foreign investors when operating in their territories. In this context, attention is first given to the notion of investment and its legality condition to activate the ISDS-before then shifting to the substantive standards related to large-scale investments in farmland. These investments are connected to their putative adverse effects, such as human rights violations. As a result, this Article delves into the extent which the legality condition of these investments is fundamental for challenging the host state's conduct or regulation. Substantive standards-such as Fair and Equitable Treatment (FET) and Full Protection and Security (FPS) - are further examined. Then, focus is given to direct and indirect expropriation and its legality requirements. The current substantive standards of protection for foreign investors and their large-scale investments in farmland under international investment law, and its related case law, are fundamental to understanding the perceived far-reaching protection system. This system is currently the object of reform to restrict investors' protections and enlarge host states' right to regulate.

Section $\mathrm{C}$ analyzes the current necessity for states to anchor their right to regulate investment treaties. States began to feel their sovereign powers were being threatened after these powers were successfully challenged by foreign investors, and as a result, a reform of substantive standards started globally. In this context, potential measures or regulations that could affect large-scale investments in farmland are examined. This Article discusses the consequences of land reform and the implementation in domestic law of internationally accepted standards to prevent human rights violations, land tenure abuses, and environmental harm. Moreover, a selected list of defenses that host states may raise during an ISDS to justify challenged conduct is also presented-with particular attention being given to the right to regulate, investor's conduct, and the state of necessity. These arguments' attempt to define the extent and the legitimacy of states' conduct under international investment law. Although this chapter is mainly focused on the right to regulate, the concept introduced here helps to define the current role of states under international investment law.

Finally, Section D tries to find a balance between the needs of foreign investors and the need of host states to equilibrate the mechanism generated under international investment law. The scope of this final chapter will go beyond the reach of this balance between these two subjects and consider a higher goal, which could potentially undermine both investor and host state: The protection of public interest. The idea is to consider all adverse impacts that large-scale investments in farmland can generate if investors do not comply with corporate social responsibility. These adverse impacts also include when the host state does not implement internationally accepted standards - which is done when the state accepts investments notwithstanding their adverse impacts on human rights, the environment, or sustainable development. 
The idea of introducing a public interest clause in investment treaties would not only be significant to prevent phenomena such as land grabbing but it would also prevent other high-risk investments. This clause would prevent both the investor and the host state from acting against the public interest and would allow relief only to actors that can demonstrate that they have acted with reasonable due diligence by operating, or allowing to operate, the investment on a specific territory.

\section{B. "Land Grabbing" and Investor's Protection Under Investment Treaties \\ I. Nature of Large-Scale Investments in Farmland}

Large-scale investments in farmland acquired international interest during the global food prices crisis of 2007-2008. ${ }^{1}$ Countries that depended on the importation of agricultural products worried about the increase and volatility of food prices. These countries saw large-scale investments in farmland as a way to shelter their food security without depending on the international market. ${ }^{2}$ In this context, foreign investors took advantage of the crisis and unstable food prices by implementing new investment opportunities. Simultaneously, investments in farmland were motivated by the new policies of developed countries towards the production of biofuels as an alternative to fossil fuels. ${ }^{3}$ This Article is mainly focused on large-scale investments in farmland involving foreign investors and the host states. The extent of these investments is usually fixed from a threshold of 1'000 ha. ${ }^{4}$ And the nature of these contracts can vary from land acquisition, the purchase of property title of land, to land lease, the payment of rent for temporary possession of land's property, ${ }^{5}$ or land concession-used to develop agricultural production, agro or biofuel production, and tourism. ${ }^{6}$ Nonetheless, most of these investments are based on lease or concession contracts with peculiar long term durations, as they can run from twenty-five to ninety-nine years with the possibility to renew. ${ }^{7}$ The targeted countries for large-scale investments in farmland are usually low or middleincome countries defined as "weak states." ${ }^{8}$ Nevertheless, this does not mean that investors originate only from high-income countries. Some foreign investors come from middleincome countries, such as Brazil, Russia, India, China, South Africa (BRICS), or the Arab Gulf. ${ }^{9}$ Because host states have largescale "unused" 10 land, they make it available to foreign investors to benefit from the investment. This can generate higher tax revenue, technology, and job

\footnotetext{
${ }^{1}$ Olivier de Schutter, How Not to Think of Land-Grabbing: Three Critiques of Large-Scale Investments in Farmland, 38 J. Peasant STUd. 249, 251 (2011).

${ }^{2}$ Hum. Rts. Council, Report of the Special Rapporteur on the Right to Food, Olivier de Schutter, Addendum - Large-Scale Land Acquisition and Leases: A Set of Minimum Principles and Measures to Address the Human Rights Challenge, A/HRC/13/ 33/Add.2 (Dec. 28, 2009), para. 12.

${ }^{3}$ Elisa Freiburg, Land Grabbing as a Threat to the Rights to Self-Determination: How Permanent Sovereignty over Natural Resources Limits States' Involvement in Large-Scale Transfers of Land, 18 MAX Planck Y.B. United Nations L. 507, 509 (2014).

${ }^{4}$ See de Schutter, supra note 2, at para. 11.

${ }^{5}$ Jochen Von Bernstorff, "Land Grabbing" und Menschenrechte: die FAO Voluntary Guidelines on the Responsible Governance of Tenure, INEF FORSCHUNGSREIHE MENSCHENRECHTE, UNTERNEHMENSVERANTWORTUNG UND NachHaltige Entwicklung, 10 (Nov. 2012) https://inef.uni-due.de; see also Center fOr HumAn Rights AND GlobaL Justice, Foreign Land Deals and Human Rights: Case Studies on Agricultural and Biofuel Investment, 110-14 (2010) http://chrgj.org/wp-content/uploads/2012/07/landreport.pdf (an unsigned land lease contract).

${ }^{6}$ On the different nature of large-scale investments in farmland, especially in Africa, see Lorenzo Cotula, LAND DEALS IN AFRICA: WHAT IS IN THE CONTRACTS? (2011), http://pubs.iied.org/pdfs/12568IIED.pdf.

${ }^{7}$ Due to lack of transparency, this information is based only on the few public contracts. See Jochen von Bernstorff, supra note 5 .

${ }^{8}$ Christian Häberli \& Fiona Smith, Food Security and Agri-Foreign Direct Investment in Weak States: Finding the Governance Gap to Avoid "Land-Grab", MoD. L. REv. 189, 192-93 (2014).

${ }^{9}$ Freiburg, supra note 3, at 509.

${ }^{10}$ Klaus Deininger et al., Rising GLOBAL INTEREST IN FARMLAND: CAN IT YIELD SUSTAINABLE AND EQUITABLE BENEFITS? 54 (2011), http://documents1.worldbank.org/curated/en/998581468184149953/pdf/594630PUB0ID1810Box358282B01PUBLIC1.pdf.
} 
opportunities for their citizens. ${ }^{11}$ Although, the so-called "unused" land may actually be "used" land by indigenous people, the indigenous peoples are entitled only to customary rights on these territories and may not have been recognized as owners of property rights under municipal law. ${ }^{12}$ This practice has generated lots of criticism since its increased implementation. Scholars usually define these investments as "land grabbing." 13 A recurring definition used by scholars is the one developed by Borras et al. in the following terms:

Contemporary land grabbing is the capturing of control of relatively vast tracts of land and other natural resources through a variety of mechanisms and forms that involve large-scale capital that often shifts resource use orientation into extractive character, whether for international or domestic purposes, as capital's response to the convergence of food, energy and financial crises, climate change mitigation imperatives, and demands for resources from newer hubs of global capital. ${ }^{14}$

Its negative connotation is due to the arguably negative socio-economic impacts that this phenomenon may generate. To some extent, large-scale investments in farmland can then be considered as land grabs because "projects that are not fully implemented can seriously undermine local livelihoods." ${ }^{15}$ In addition, land grabbing can generate a loss of customary land tenure rights for indigenous people, unjustified forced evictions, harmful consequences for the environment, and food insecurity. Because of this, the Principles for Responsible Agricultural Investment that Respect Rights, Livelihoods and Resources (RAI Principles) were adopted in 2010 by FAO, International Fund for Agricultural Development, UN Conference on Trade and Development (UNCTAD) and WBG to avoid adverse effects engendered by large-scale investments in farmland. ${ }^{16}$ Notwithstanding the importance of adopting these principles, the acceptation of the latter came not without criticism. For instance, the former Special Rapporteur on the right to food, Olivier de Schutter, argued that RAI Principles, in some way legitimate the practice of large-scale investments in farmland-a practice which should not be promoted to achieve an active rural development. ${ }^{17}$ Despite this, some authors note that foreign direct investment in farmland can improve a host state's national food security-but weak states must improve their governance structures in order to take advantage of these investments. ${ }^{18}$

Irrespective of the putative positive benefits or adverse effects on sustainable development and global food security, large-scale investments in farmland are still currently in use, especially by foreign investors in weak states. In this context, examining how and to what extent those investments can be managed and protected under international investment law may generate for host states, and foreign investors, more awareness of the implications of these significant investments-which involve fundamental rights of third actors. Because large-scale investments in farmland are always connected to their putative adverse effects, such as human rights violations, the following discusses

\footnotetext{
${ }^{11} I d$. at xxxiii.

${ }^{12}$ Hum. Rts. Council, Report of the Special Rapporteur on the Right of Indigenous People, Victoria Tauli-Corpuz, A/HRC/33/ 42 (Aug. 11, 2016) paras. 16, 33.

${ }^{13}$ The term "land grabbing" is still disputed in the academic field. See Freiburg, supra note 3, at 509; see also Martin Delaroche, New Regulations on Foreign Acquisition of Land in Brazil and Argentina, Y.B. ON INT'L INV. L. \& POL'Y 2013-2014 569, 576 (2015).

${ }^{14}$ Saturnino M. Borras et al., Land Grabbing in Latin America and the Caribbean, 39 J. PeASANT STUD. 845, 851 (2012).

${ }^{15}$ See Deininger et al., supra note 10 , at 68.

${ }^{16} \mathrm{FAO}, \mathrm{IFAD}, \mathrm{UNCTAD} \&$ The World Bank Group, Principles for Responsible Agricultural Investment that Respects Rights, Livelihoods and Resources 1 (Jan. 25, 2010) http://documents.worldbank.org/curated/en/748861468194955010/pdf/103520WP-PUBLIC-PRINCIPL.pdf.

${ }^{17}$ See de Schutter, supra note 1.

${ }^{18}$ Häberli \& Smith, supra note 8, at 194.
} 
how the legality condition of these investments is fundamental for challenging the host state's conducts or regulations.

It is vital to establish if the investor's activity implemented on the host state's territory can be defined as an investment to activate the investor's protection. Under most Bilateral Investment Treaties (BITs), the broad form of "every kind of assets" is used to define an investment. Therefore, large-scale investments in farmland through real estate purchase contracts for agricultural production, land lease contract, or concession contracts should be identified as investments-at least in an investment treaty with a broad definition of investment. Nevertheless, not all kinds of investments deserve protection. Most investment treaty provisions imply the host state's consent to ISDS only for investments obtained "in accordance with the law." Therefore, an investment can acquire international protection only if it is made in conformity with the host state's law. Depending on the provision's wording, only in the case where an investment is unlawful $a b$ initio will the arbitral tribunal lack jurisdiction on the dispute, given that it is not arbitrable. ${ }^{19}$

As there is inconsistent use of the words "jurisdiction" and "admissibility," it is more suitable to use the words arbitrability as the fundamental condition to exert jurisdiction and admissibility as the faculty to not exert jurisdiction till the claim is considered admissible. ${ }^{20}$ In the award in Yukos v. Russia, the arbitral tribunal recognizes that, under investment law, if the applicable treaty does not provide a legality condition and an investment was made in breach of the law of the host state the illegal investment may: "(a) not qualify as an investment, thus depriving the tribunal of jurisdiction; or (b) be refused the benefit of the substantive protections of the investment treaty." ${ }^{21}$ In this context, (a) is not arbitrable, and (b) is inadmissible. If the illegal conduct of an investor is subsequent, the arbitral tribunal will probably recognize its jurisdiction and treat the claim under the admissibility or even the legal merits. By contrast, under the unclean hands doctrine, a claim may be entirely dismissed without considering the host state's conduct, because of misconduct by the investors. ${ }^{22}$ The Unclean hands doctrine was discussed in Yukos v. Russia. The arbitral tribunal concluded that the latter is not a general principle of law pursuant to Article 38 para 1 lit (c) of the International Court of Justice (ICJ) Statute. ${ }^{23}$ Therefore, it is worth distinguishing that when there is an illegal investment $a b$ initio, the arbitral tribunal may declare lack of jurisdiction due to lack of arbitrability. On the contrary, if there is illegal conduct by the investor after obtaining the investment, the arbitral tribunal will not only recognize jurisdiction based on the admissibility condition, but also treat the claim under legal merits and consider the illegal conduct when assessing liability and damages. ${ }^{24}$

In conclusion, large-scale investments in farmland can be considered investments under international investment law. They deserve international protection only if they were legally obtained, but also in the case of ex-post illegal conduct by the investor because the illegal conduct could be contemplated by assessing the investor's claim for relief.

\section{Substantive Standards: FET, FPS, and Focus on Expropriation}

Under international investment law, an investor can directly raise claims challenging measures adopted by the host state. Investment treaties provide substantive standards that can give a cause

\footnotetext{
${ }^{19}$ Rahim Moloo \& Alex Khachaturian, The Compliance with the Law Requirement in International Investment Law, 34 FORDHAM INT'L L.J. 1473, 1481-82 (2011).

${ }^{20}$ David A. R. Williams, Jurisdiction and Admissibility, in The OXFORD HANDBOOK OF INTERNATIONAL INVESTMENT LAW 927 (Peter Muchlinski, et al. eds., 2008).

${ }^{21}$ Yukos Universal Limited (Isle of Man) v. The Russian Federation, Perm. Ct. Arb. Case No. 04/AA227, Final Award, PCA Case Repository 1349 (July 18, 2014).

${ }^{22}$ Aloysius Llamzon, Yukos Universal Limited (Isle of Man) $v$ The Russian Federation: The State of the 'Unclean Hands' Doctrine in International Investment Law: Yukos as both Omega and Alpha, 30 ICSID REV - FOREIGN INV. L.J. 315, 317 (2015).

${ }^{23}$ Yukos, PCA Case No. 04/AA227 at 1358, 1363.

${ }^{24} \mathrm{Id}$. at 1374 .
} 
of action to the investor in order to challenge and find relief against an alleged breach of the investment treaty by the host state. Many investment treaties imply the absence of a universal notion of substantive standards, and their interpretation can change with the wording of one provision. Nonetheless, in most treaties, substantive standards contain the same or similar wording, and the interpretation of these provisions by arbitral tribunals - even though sometimes lacking unanimous interpretation due also to the absence of stare decisis or jurisprudence constantemay help define the protection's extent of those provisions. Among the substantive standards included in this article, such as FET and FPS, additional focus is applied to direct and indirect expropriation. These standards are presented and put together in the context of large-scale investments in farmland to evaluate to what extent an investor can find relief based on a putative breach of these international standards.

\section{Fair and Equitable Treatment}

FET standard is an international obligation for the host state to treat foreign investors in a fair and equitable manner. The notion of fair and equitable is broad. The typical provision of FET provides that "[e]ach Contracting Party shall ensure fair and equitable treatment." Sometimes the same provision can also add a reference to customary international law, a minimum standard of protection, or international law. Notwithstanding the debate over a putative existing difference between an autonomous treaty's FET standard and the customary international law minimum standard, ${ }^{25}$ it is possible to infer standard FET features. As Schill pointed out, there are seven principles that can be deduced under the FET standard: (1) stability, predictability and consistency of the legal framework; (2) legality; (3) legitimate expectations' protection; (4) procedural due process and denial of justice; (5) substantive due process and protection against discrimination and arbitrariness; (6) transparency; and (7) reasonableness and proportionality. ${ }^{26}$ If at least one of the aforementioned principles is breached, there is a violation of the FET provision.

Granting stability and predictability of the municipal legal framework is undoubtedly an excellent benefit for the investors for managing the investment well and avoiding risk-related consequences-considering that a sudden change in the legal framework can obstruct the investment if it affects the acquired land rights of the investor. As property rights are supposed to be unlimited, and the lease or concession contracts usually have a long-term duration, the investor in farmland can receive a tremendous substantive guarantee under this principle. Nevertheless, this principle does not mean that the host state framework cannot be changed. ${ }^{27}$ Therefore, it is utopic to think that during a ninety-nineyear lease contract, a host state will not change its legal framework. Furthermore, another significant investors' protection related to large-scale investment in farmland is the protection of their legitimate expectations, which sometimes correlates with the legal framework stability. This principle is not an absolute one, either. Investor's legitimate expectations must be reasonable and, in principle, the change of the legal framework must be strongly related to the commitments that the host state guaranteed when attracting the foreign investor within its territory, if it is to be considered a breach of the FET standard. ${ }^{28}$

Therefore, a FET-based claim can be raised if the host state neglects to respect its commitments by fundamentally altering the legal framework which the investors had reasonably relied on. This provision is especially important for long term investments, including large-scale investments in farmland. Even if a former government had previously taken some commitments, a newly elected government could nevertheless develop new policies against fulfilling those commitments and thus breach the FET standard. To skirt international liability, an incoming government has to

\footnotetext{
${ }^{25}$ Stephan W. Schill, Fair and Equitable Treatment, the Rule of Law and Comparative Public Law, in INTERNATIONAL Investment Law and Comparative Public Law 152-53 (Stephan W. Schill ed., 2010).

${ }^{26} I d$. at $159-60$.

${ }^{27} I d$. at $161-62$.

${ }^{28} I d$. at $166-74$.
} 
respect those commitments and avoid changing the investment environment granted by the former government. This is a challenging task for the host state because the stability of a legal framework can concern far-reaching prerogatives-such as regulations on taxation, on water supply, and on the environment. In order to prevent these investments' risks, a stabilization clause is usually stipulated under the contract defining the large-scale investments in farmland between investor and host state. ${ }^{29}$ In signing a stabilization clause, the host state promises not to change its legal framework on domains affecting the investment environment during the investment period. Stabilization clauses function to freeze the effect of a legal framework at the time of the investment's admission. ${ }^{30}$ Alternatively, as defined by Schreuer, stabilization clauses do not prevent change in legal frameworks, but rather protect the investor from the adverse result of these changes. $^{31}$ Thus, stabilization clauses aim at protecting the investor in case of a change in the legal framework regarding compensation, and can render inapplicable the changed legal framework for the investor. ${ }^{32}$

Stabilization clauses are usually confined in a domain such as tax law ${ }^{33}$ and are usually stipulated in long-term investment contracts. ${ }^{34}$ By contrast, in a research conducted by Cotula on land deals in Africa in which he had the opportunity to examine twelve investment contracts on largescale investments in farmland, ${ }^{35}$ he found that some of those contracts provided broad stabilization clauses. The latter are far-reaching because stabilization clauses allow the investment contract to prevail on any future changes in the legal framework that could directly or indirectly affect the investment. ${ }^{36}$ Because an infringement of these clauses implies an obligation to repair the contract damages, ${ }^{37}$ the investors have a strong guarantee that host states will not engage in arbitrary conduct and dispose of them once the infrastructures needed to cultivate the land are completed. ${ }^{38}$ Nevertheless, the stabilization clause here can freeze not only potential arbitrary regulation but also bona fide regulation in the public interest. ${ }^{39}$ This is because the implementation of environmental, social, labor, and human rights standards can indirectly affect the irrigations cost and violate the stabilization clause. ${ }^{40}$ Within the investment treaty's provision, these stabilization clauses are of significant importance concerning a putative breach of the FET standard due to the predictability and stability of the legal framework as well as the legitimate expectations. If, despite the stabilization clause, the legal framework is changed, however, the arbitral tribunal will most likely ascertain a breach of the FET standard. ${ }^{41}$ For example, in Philip Morris v. Uruguay the arbitral tribunal observed that in the absence of a stabilization clause, a change of legal framework is not absolutely prevented by the FET standard. ${ }^{42}$

\footnotetext{
${ }^{29}$ Federica Violi, The Practice of Land Grabbing and Its Compatibility with the Exercise of Territorial Sovereignty, in Natural Resources Grabbing: An International Law Perspective, 24 (Francesca Romanin et al. eds., 2015).

${ }^{30}$ Christoph Ohler, Concessions, in Max Planck Encyclopedia of Public International Law 27 (2013).

${ }^{31}$ Christoph Schreuer, Investment Disputes, in Max Planck Encyclopedia of Public International Law 40 (2013).

${ }^{32}$ Moshe Hirsch, Between Fair and Equitable Treatment and Stabilization Clause: Stable Legal Environment and Regulatory Change in International Investment Law, 12 J. WorLd INV. Trade 783, 787 (2011).

${ }^{33}$ Duke Energy International Peru Investment No. 1 Ltd v. Republic of Peru, ICSID Case No. ARB/03/28, Award ICSID Repository, paras. 186-87, 210-28 (Aug. 18, 2008).

${ }^{34}$ Hirsch, supra 32 , at 787-88.

${ }^{35}$ Cotula, supra 6 , at 1 .

${ }^{36} I d$. at 39.

${ }^{37}$ Irmgard Marboe \& August Reinisch, Contracts between States and Foreign Private Law Persons, in MAX PLANCK Encyclopedia of Public International Law 12 (2011).

${ }^{38}$ Cotula, supra 6, at $39-40$.

${ }^{39} \mathrm{Id}$. at 40 .

${ }^{40} I d$.

${ }^{41}$ Peter Muchlinski, 'Caveat Investor'? The Relevance of the Conduct of the Investor under the Fair and Equitable Treatment Standard, 55 INT'L \& COMP. L. Q. 527, 551-52 (2006).

${ }^{42}$ Philip Morris Brands Sarl, Philip Morris Products SA and Abal Hermanos SA v. Oriental Republic of Uruguay, ICSID Case No. ARB/10/7, Award, ICSID Repository, para. 423 (July 8, 2016).
} 
Stabilization clauses can be broad and are likely to result in a breach of the FET standard even in cases in which the host state legislates to improve social and environmental standards. For this reason, it is recommended for the host states-especially for weak states - to not undertake such broad commitments. ${ }^{43}$ When a legal framework is conceived to achieve sustainable development, it is counter-productive to exempt the foreign investor from the application of the new law or to prevent the host state from adopting it. Nevertheless, by applying new generation investment treaties, an arbitral tribunal may question the validity of such clauses in relation to FET standard because the scope of these investment treaties is promoting sustainable development. ${ }^{44}$

A FET breach can also occur when the host state does not maintain its commitments. For instance, in von Pezold and Others v. Zimbabwe, the claimants-property owners of large-scale investment in agribusiness-were expropriated due to land reform. ${ }^{45}$ Among other claims, the investors raised the breach of FET standard. The arbitral tribunal concluded that Zimbabwe breached the FET standard after the enactment of the Constitutional Amendment of $2005 .{ }^{46}$ The government at the time issued a "Note Verbale" declaring that the Amendment did not involve the claimant's properties because they were owners of agricultural land and protected by an investment treaty. ${ }^{47}$ Nonetheless, in 2007, the "Government of Zimbabwe changed its mind and declared that the Constitutional Amendment had expropriated their investments." ${ }^{38}$ Thus, the arbitral tribunal concluded that this conduct breached the FET obligations. ${ }^{49}$

The FET standard is normally examined by balancing the interests of host state and foreign investors using the principles of proportionality-notably, Principle 7 as pointed out by Schill. Consequently, the FET standard is a flexible one. ${ }^{50}$

\section{Full Protection and Security}

FPS is an obligation for the host state to grant physical security to foreign investments against interference by third actors or the state itself. ${ }^{51}$ This standard is not an absolute one, either. The host state must take all reasonable, necessary, or proportionate measures ${ }^{52}$ to protect the investment-and as such, it is a due diligence obligation. ${ }^{53}$ Under this provision, physical and material protection are granted both to the investor and the investment. By contrast, there are also opinions indicating that the FPS standard goes beyond the physical protection and reaches the legal protection. ${ }^{54}$ Moreover, due to the amended language, FPS can sometimes be granted under the FET standard instead of as an independent standard.

The FPS clause implies, for large-scale investments in farmland, that the host state has to take all measures to remove civilians occupying the investor's properties, for instance. The host state breaches the standard if the police fail to protect and do not act responsively. ${ }^{55}$ Also, the FPS clause concerning investments in farmland can raise difficulties between the protection of conflicting

\footnotetext{
${ }^{43}$ Cotula, supra note 6 , at 40 .

${ }^{44}$ See infra Section C.

${ }^{45}$ Bernhard von Pezold \& Others v. Republic of Zimbabwe, ICSID Case No. ARB/10/15, Award, ICSID Repository (Jul. 28, 2015).

${ }^{46} I d$. at paras. $116-17$. The amendment dealt with land reform and subsequent land expropriation.

${ }^{47} I d$. at paras. $547-48$.

${ }^{48}$ Bernhard von Pezold \& Others, ICSID Case No. ARB/10/15 at para. 549.

${ }^{49}$ Id. at para. 551 .

${ }^{50}$ Schill, supra note 25 , at 170 .

${ }^{51}$ Helge Elisabeth Zeitler, Full Protection and Security, in InTERnational Investment LaW And Comparative Public LAW 190-92 (Stephan W. Schill ed., 2010).

${ }^{52}$ On these three notions in relation to FPS, see $i d$. at 206-08.

${ }^{53} \mathrm{Id}$. at 199.

${ }^{54} I d$. at 195.

${ }^{55}$ Bernhard von Pezold \& Others, ICSID Case No. ARB/10/15 at para. 597.
} 
rights. ${ }^{56}$ For example, property rights over real estate can be in contrast with the customary land rights of indigenous people.

\section{Focus on Expropriation}

An investor can also raise claims based on an alleged breach of the expropriation provision. Expropriation is an act by sovereign states in relation to their territories and natural resources, which can affect the acquired rights of foreign investors. International investment law developed substantive standards that host states have to respect when acting under their legitimate exercise of sovereignty to balance these two main rights. Depending on the host state's measures, investors can raise a claim defending a seizure of their property rights or for deprivation of their investments without compensation. The substantive standard on the prohibition to expropriate without compensation is a significant guarantee for the investor's protection in large-scale investment in farmland. As mentioned before, large-scale investments in agribusiness can be based on a real estate property, as a large-scale land acquisition, or based on the grant or use of the land through concessions or lease contracts. ${ }^{57}$ As these investments can be directly or indirectly affected by a host state's conduct, it is useful to examine the recent development of expropriation in international investment law. Usually, the existence of expropriation is recognized by an arbitral tribunal, then its lawfulness or unlawfulness must be examined considering whether-or to what extent-compensation or reparation is due. Before showing the main differences and consequences between lawful and unlawful expropriation and the related issue on compensation, it is useful to present the main differences between direct and indirect expropriation.

\subsection{Direct and Indirect Expropriations}

Direct expropriation refers to a host state taking foreign investment through seizure or transfer of title to the host state or a third beneficiary. ${ }^{58}$ Direct expropriation takes place when there is a permanent deprivation of the investment not justifiable by the police powers doctrine. Typical host state permanent takings that are not elevated to the level of direct expropriation include forfeiture of property due to criminal activity. ${ }^{59}$ The police powers doctrine dealing with direct expropriation seems to be applied narrowly, as demonstrated by the often quoted Santa Elena award. ${ }^{60}$ Following the reasoning of the arbitral tribunal in Quiborax v. Bolivia, dealing with the revocation of a mining concession due to the alleged claimant's violation of domestic law of the host state, the

\footnotetext{
${ }^{56}$ On this, see Zeitler, supra note 51 , at 210 .

${ }^{57}$ See infra Section B.I.

${ }^{58}$ In Burlington v. Ecuador, a decision on liability, the arbitral tribunal stated that direct expropriation under the applicable treaty provides three requirements: "(i) the measure deprives the investor of his investment; (ii) the deprivation is permanent; and (iii) the deprivation finds no justification under the police powers doctrine." Burlington Resources Inc v. Republic of Ecuador, ICSID, Case No. ARB/08/5, Decision on Liability, ICSID Repository, para. 506 (Dec. 14, 2012). The arbitral tribunal in Quiborax v. Bolivia grounded its examination on direct expropriation on these three elements as well, recognizing that these three standards are the most relevant elements for arbitral tribunals when deciding on the existence of direct expropriation. Quiborax S. \& Non Metallic Minerals SA v. Plurinational State of Bolivia, ICSID Case No. ARB/06/2, Final Award, ICSID Repository, para. 200 (Sept. 16, 2015).

${ }^{59}$ These takings are internationally recognized to be justified by the police powers doctrine and do not engender international liability of the state. See Andrew Newcombe \& Lluis Paradell, Expropriation, in LAW AND PRACTICE IN InVEstment Treaties: Standard of Treatment 321, 324 (2009).

${ }^{60}$ Compañía del Desarrollo de Santa Elena SA v. Republic of Costa Rica, ICSID Case No. ARB/96/1, Award, ICSID Repository, para. 72 (Feb. 17, 2000):

Expropriatory measures - no matter how laudable and beneficial to society as a whole - are, in this respect similar to any other expropriatory measures that a state may take in order to implement its policy: where property is expropriated, even for environmental purpose, whether domestic or international, the state's obligation to pay compensation remain.

However, this arbitral tribunal had to deal uniquely with the compensation-based claim of a lawful expropriation only seeking compensation, and therefore the existence of a direct expropriation was not disputed.
} 
police powers doctrine could have legitimated the host state's measure. ${ }^{61}$ The reasoning was justified by the peculiarity of the requirements to maintain a license or a concession. ${ }^{62}$ Therefore, investors in farmland dealing with the taking of their investment by the state can receive protection under the investment treaty only if the direct taking can be elevated to be a direct expropriation. According to Häberli and Smith, direct expropriations are given when the host state revokes, without compensation, land rights granted to the investor by a former government-but these expropriations can also occur if the state adopts an export prohibition of biofuels and crops during a global food crisis, or due to poor harvest. ${ }^{63}$

Indirect expropriation takes place when there is no transfer of property, but the measures adopted by the state have the effect of direct expropriation for the investment. The legal title to the property representing the investment is not affected, but the measures taken provoke interferences with the investor's rights. ${ }^{64}$ As confirmed in the case Philip Morris v. Uruguay, an indirect expropriation is given when there is a substantial deprivation of the investment. ${ }^{65}$ Similar to the case with direct expropriation, measures of the state involving substantial deprivation of the investments can be justified by the police powers doctrine, and as such, they are not elevated to the level of indirect expropriation. ${ }^{66}$ Even though the police powers doctrine seems to have acquired some acceptance by arbitral tribunals, ${ }^{67}$ it is still disputed if a regulatory measure is to be seen as non-expropriatory by the sole justification of the legitimate public purposes. ${ }^{68}$ The award in Philip Morris v. Uruguay clears up the issue. In Philip Morris v. Uruguay, the arbitral tribunal held that regulatory measures do not constitute an indirect expropriation when the action implies a host state's bona fide conduct aiming at protecting public welfare, as long as it is nondiscriminatory and proportionate. ${ }^{69}$ Häberli and Smith observe that some regulatory measures in large-scale investments in farmland such as the implementation of RAI Principles or general implementation of human rights obligation within the host state territory, could be justified by the police powers doctrine. ${ }^{70}$

Finally, it is worth pointing out that the police powers doctrine is more developed when dealing with indirect expropriation than with direct expropriation. The interpretation of the doctrine seems to be narrower when property is expropriated. This may imply that large-scale investors in farmland are better protected as landowners in a direct expropriation, rather than against an indirect measure that deprives the investors of their investments' value because the latter would be easier to justify under the police powers doctrine. ${ }^{71}$

\subsection{Legality of Expropriations}

Once a non-justifiable taking is identified, it must be examined to determine if the expropriation is lawful or unlawful. Most investment treaties provide the following criteria to legally expropriate: Public purpose, non-discrimination, due process, and compensation. ${ }^{72}$ First, the public purpose is

\footnotetext{
${ }^{61}$ Quiborax, ICSID Case No. ARB/06/2 at para. 207.

${ }^{62} I d$. at para. 206.

${ }^{63}$ Häberli \& Smith, supra note 8 , at 213.

${ }^{64}$ Philip Morris, ICSID Case No. ARB/10/7 at para. 191.

${ }^{65} \mathrm{Id}$. at para. 286.

${ }^{66}$ August Reinisch, Expropriation, in THE OXFORD HANDBOOK OF INTERNATIONAL INVESTMENT LAW 433 (Peter Muchlinski et al. eds., 2008).

${ }^{67}$ Saluka Investments BV v. The Czech Republic, Perm. Ct. Arb. Case No. 2001-4, Partial Award, PCA Case Repository, para. 262 (Mar. 17, 2006).

${ }^{68}$ Reinisch, supra note 66 , at 438.

${ }^{69}$ Philip Morris, ICSID Case No. ARB/10/7 at para. 305.

${ }^{70}$ Häberli \& Smith, supra note 8 , at 213-14.

${ }^{71}$ In this line, see Bilateral Investment Treaty, Annex B, Expropriation (4b), U.S.-Uru., Nov. 4, 2005, that entails exceptions on indirect expropriation, but no exception is provided for direct expropriation.

${ }^{72}$ August Reinisch, Legality of Expropriations, in Standards of InVESTMENT Protection, 176-78 (August Reinisch ed. 2008).
} 
usually motivated by the sovereign power of a state. Typically, a lack of public purpose is given when the expropriated investment is transferred for private gain-as can be the case when it is transferred to the politic elite. ${ }^{73}$ In the award in von Pezold and Others v. Zimbabwe, the arbitral tribunal, by examining the lawfulness of the expropriation of part of claimants' proprieties, decided that there was no evidence that the redistribution of expropriated land "was in the public interest or served a genuine public purpose."74 Notwithstanding the peculiarity of the facts, the arbitral tribunal found that the alleged public purpose of redistributing land to compensate for historical wrongs was not achieved. This happened because the historically disadvantaged or landless population had not received the property back, as a large part of the property was still in possession of the claimants. ${ }^{75}$ Second, the non-discrimination standard is related to the prohibition of nationality and racial discrimination. ${ }^{76}$ In the award in von Pezold and Others v. Zimbabwe, the arbitral tribunal held that the expropriation was discriminatory because it was based on racial discrimination. ${ }^{77}$ Third, the due process requirement varies depending on the wording of the expropriation's provision. Nevertheless, it can be generally inferred that the due process requirement implies that expropriation must follow the host state's national law and that the legal avenues to challenge the measure were available. ${ }^{78}$ Finally, the compensation requirement has been disputed recently. This is because an expropriation must be compensated to be legal. Still, when arbitral tribunals deal with expropriation, it is possible that the host state has not yet paid the due amount because it was still disputed ${ }^{79}$ or because the host state did not elevate its measure to an expropriation. ${ }^{80}$ Nevertheless, if the other requirements are met and there was an offer to compensate, ${ }^{81}$ the expropriation can be held as lawful, ${ }^{82}$ or at least, provisionally lawful. ${ }^{83}$

\subsection{Compensation}

In general, compensation is necessary during lawful expropriation ${ }^{84}$ because it is required by most of the investment provisions. The compensation calculation may vary by the wording of the treaty, and it may also provide the Hull formula, or a formula for "just compensation." ${ }^{85}$ Most investment treaties do not provide how to determine compensation or reparation if the expropriation is unlawful. ${ }^{86}$ Usually, arbitral tribunals rely on customary law founded in the Chorzow Factory case from the Permanent Court of International Justice (PCIJ). According to this case, when there is legal expropriation, compensation is "limited to the value of the undertaking at the moment of the dispossession, plus interest to the day of payment." ${ }^{87}$ In contrast, if there is an unlawful expropriation, "the reparation must-as far as possible-wipe out all the consequences of the illegal act and reestablish the situation which would, in all probability, have existed if the act had not been

\footnotetext{
${ }^{73} \mathrm{Id}$. at 179.

${ }^{74}$ Bernhard von Pezold \& Others, ICSID Case No. ARB/10/15 at para. 502.

${ }^{75} \mathrm{Id}$.

${ }^{76}$ ReINISCH, supra note 72 , at 190.

${ }^{77}$ Bernhard von Pezold \& Others, ICSID Case No. ARB/10/15 at para. 501 ("[T] he evidence supports a conclusion that the Claimants were targeted as a result of their skin color.”).

${ }^{78}$ REINISCH, supra note 72 , at 193.

${ }^{79}$ Tidewater Invs. SRL \& Tidewater Caribe C.A. v. Bolivarian Republic of Venezuela, ICSID Case No. ARB/10/5, Award, ICSID Repository, paras. 145-46 (Mar. 13, 2015).

${ }^{80}$ Quiborax, ICSID Case No. ARB/06/2 at para. 255.

${ }^{81}$ Tidewater, ICSID Case No. ARB/10/5 at paras. 129-46.

${ }^{82}$ ReINISCH, supra note 72 , at $198-99$.

${ }^{83}$ Tidewater, ICSID Case No. ARB/10/5 at para. 141. By contrast, in the award from Bernhard von Pezold \& Others $v$. Zimbabwe, the arbitral tribunal evaluated the unlawfulness of the expropriation based on the absence of compensation, and dealt with the other requirements only ad abundantiam. See Bernhard von Pezold \& Others, ICSID Case No. ARB/ $10 / 15$ at para. 497.

${ }^{84}$ ReINISCH, supra note 72, at 199.

${ }^{85}$ See also id. at $194-99$.

${ }^{86}$ See, e.g., Bernhard von Pezold \& Others, ICSID Case No. ARB/10/15 at para. 758.

${ }^{87}$ The Factory at Chorzow (Ger. v. Pol.), Claim for Indemnity, 1928 P.C.I.J., (ser. A) No. 17, at para. 47 (Sep. 13).
} 
committed." 88 This implies that reparation can be calculated on the day of the award and thus allow the arbitral tribunal to assess the reparation amount on ex post data. ${ }^{89}$ In the award from von Pezold and Others $v$. Zimbabwe, the arbitral tribunal decided on the restitution of the expropriated properties. If Zimbabwe does not restitute the properties, the amount is calculated on the day of the award due to the increased value of the investment after it had been unlawfully expropriated. Therefore, if Zimbabwe did not perform restitution, it is required to compensate the investors with the increased value of the properties at the time of the award. ${ }^{90}$ By contrast, if restitution takes place and the investment loses part of its value during the expropriation, the arbitral tribunal can assess compensation for the suffered losses. ${ }^{91}$

In conclusion, the substantive standards can offer far-reaching international protection to investors in farmland. Except in cases where investments are illegal ab initio, investors have many chances to challenge the host state's conduct that interferes directly or indirectly with their investments. Therefore, the next step in this analysis is examining the regulatory space left for the host state to exercise its sovereign power.

\section{Host State's Right to Regulate and Defenses in Large-Scale Investments in Farmland}

In the last decade, new models of investment treaties have been negotiated. One of the concerns that led to the emergence of new investment treaties is the need for the host states to preserve their right to regulate. This need has to be balanced against the need to protect the host states' sovereignty-which is threatened by far-reaching protections provided to investors in these treaties and by the sometimes incoherent interpretation of the substantive provisions of arbitral tribunals. ${ }^{92}$ One may argue that these reforms were first launched by low or middle-income countries, which are, for the most part, host states rather than home states. But as investment flows no longer move uniquely in a North-South direction, developed countries were the pioneers of preserving their right to regulate while maintaining international protection for their national investors abroad. For instance, developed countries, such as the USA and Canada experienced the role of host States due to the North American Free Trade Agreement (NAFTA) — and as such, these two countries developed new BIT models to preserve their right to regulate. ${ }^{93}$ In addition, the EU is going through this process as well. In the EU system, Member States not only aim at protecting national investors abroad, they also aim to improve their right to regulate to prevent future investment treaty claims. ${ }^{94}$ By reforming investment treaties, states have started to redefine provisions in a narrow way, such as the FET standard and the indirect expropriation. States have also begun introducing general exceptions to their investment provisions, some of them modeled on those characterizing trade agreements. ${ }^{95}$ Along these same lines, it is believed that new investment treaties are characterized by the switch from investment-protection-based treaties to investment for

\footnotetext{
${ }^{88} I d$.

${ }^{89}$ Quiborax, ICSID Case No. ARB/06/2 at para. 379. For this issue in particular, note the partially dissenting opinion of one arbitrator. Id.

${ }^{90}$ Bernhard von Pezold \& Others, ICSID Case No. ARB/10/15 at para. 763.

${ }^{91}$ Wena Hotels Ltd. v. Arab Republic of Egypt, ICSID Case No. ARB/98/94, Award, ISCID Repository, paras. 100-01, 118 (Dec. 8, 2008).

${ }^{92}$ Suzanee A. Spears, The Quest for Policy Space in a New Generation of International Investments Agreements, 13 J. INT'L ECON. L. 1037, 1042-48 (2010).

${ }^{93}$ Armand De Mestral, When Does the Exception Become the Rule? Conserving Regulatory Space under CETA, 18 J. INT'L ECON. L. 641, 649 (2015).

${ }^{94}$ European Federation for Investment Law and Arbitration, A Response to the Criticism Against ISDS, 6-7, 41 (May 17, 2015), http://efila.org/wp-content/uploads/2015/05/EFILA_in_response_to_the-criticism_of_ISDS_final_draft.pdf [hereinafter EFILA].

${ }^{95}$ Lorenzo Cotula, 'Land Grabbing' and International Investment Law: Toward a Global Reconfiguration of Property?, Y.B. ON INT'L INV. L. \& POL'Y 2014-2015, 203-04 (2016).
} 
sustainable development protection. ${ }^{96}$ In the next subsection, these new trends are examined in relation to large-scale investments in farmland. Also, an overview of hoststate measures that may affect large-scale investments in farmland is presented together with defenses that a host state may invoke during an ISDS.

\section{Measures Affecting Large-Scale Investments in Farmland}

The host state's duties originate from both municipal and international law. Every state has the international obligation to act in conformity with international law-pacta sunt servanda as also provided under Article 26 of the Vienna Convention on the Law of Treaties (VCLT) - and also in conformity with its domestic constitution. These legal instruments both grant and limit the power of host states to regulate. Under international investment law, states have always enjoyed sovereign power to regulate, though it was not explicitly recognized in treaties. Certain host states' decisions or measures that are taken in the public interest can potentially undermine investor's rights. Therefore, some omissions or actions taken to protect the investor can potentially undermine the public interest or the nationals' rights. Thus, the host state's task is to find a balance between this collision of rights by improving its welfare without undermining investors' rights. As stated by an arbitral tribunal in a recent award, "[s] tate policy must be able to evolve in order to guarantee adequate infrastructure and services in time and thereby the fair and equitable treatment of investments." 97 Large-scale investments in farmland are suitable examples to stress the difficulty of finding the balance between an investment's protection and development of public welfare. In this context, the relationship between the host state's obligations to protect investments in farmland and that of improving public welfare is analyzed in the following subsections.

As mentioned in Section B, there are certain host state measures that can directly or indirectly interfere with investments in farmland. It is not the goal of the present subsection to present all possible measures affecting investments in farmland. Nevertheless, there are some measures that are more likely to be adopted by weak states to develop and improve their welfare. For instance, the FAO Voluntary Guidelines on the Responsible Governance of Land Tenure (VGGT) indicate that redistributive reform of land can be an appropriate measure for broad and equitable access to land. ${ }^{98}$ This implies that some states may see it as a good practice to expropriate private land. ${ }^{99}$ Moreover, the VGGT suggest that restitution of land to people who lost legitimate tenure rights can also be an appropriate measure. ${ }^{100}$ In this context, land reform can be seen as a redistributive reform for disadvantaged groups, such as rural farmers, or a reallocation of land for people who have suffered a historical wrong. Furthermore, the implementation of international recommendations for improving human rights, land tenure rights, and the environment is also analyzed.

\section{Land Reform}

Land reform is one of the most invasive state measures affecting large-scale investments in farmland because it deprives foreign investors of properties. It is not surprising that the controversial land reform conducted by Zimbabwe during its independence was challenged at least three times by foreign investors in different fora. Two were related to BITs and the other to the Treaty of the

\footnotetext{
${ }^{96}$ United Nations Conference on Trade and Development, IIA Issues Note 1: Taking Stock of IIA Reform, 5, UNCTAD (March 2016), http://unctad.org/en/PublicationsLibrary/webdiaepcb2016d3_en.pdf.

${ }^{97}$ Mamidoil Jetoil Greek Petroleum Products Societe S.A. v. Republic of Albania, ICSID Case No ARB/11/24, Award, ICSID Repository, para. 617 (Mar. 30, 2015).

${ }^{98}$ Food and Agriculture Organization of the United Nations, Committee on World Food Security, Voluntary Guidelines on the Responsible Governance of Tenure of Land, Fisheries and Forest in the Context of National Food Security (2012), http:// www.fao.org/docrep/016/i2801e/i2801e.pdf [hereinafter VGGT].

${ }^{99} I d$. at para. 15.1 .

${ }^{100} I d$. at para. 14.1 .
} 
Southern African Development Community. ${ }^{101}$ While the claimants in Funnekotter and Others $v$. Zimbabwe were deprived of their properties between 2000-2001 without receiving compensation, ${ }^{102}$ the properties involved in the von Pezold and Others decision were expropriated through formal nationalization in $2005 .{ }^{103}$ In these two awards, arbitral tribunals found a breach of the expropriation provision. In the Campbell decision, the Southern African Development Community Tribunal (SADCT) ascertained that the applicant suffered racial discrimination, and Zimbabwe was directed to pay compensation for the compulsorily acquired lands. ${ }^{104}$ Despite its controversial character, Zimbabwe's land reform shows the peculiarity and difficulty of land reform in weak states with historical wrongs. The SADCT pointed out that a land reform to right historical wrongs can be legitimately performed if it is objective, includes fair compensation, and the expropriated land is indeed redistributed to poor, landless, or other legitimate beneficiaries. In this way, if Zimbabwe had performed the land reform following these three above mentioned requirements, the differential treatment of the applicants would not have been held as racial discrimination. ${ }^{105}$ Nevertheless, in the dissenting opinion, Judge Tshosa observed that the Zimbabwean land reform did not target white people as such, but large-scale owners of agricultural land. The fact that, due to the historical background of Zimbabwe, large-scale owners were white did not, in and of itself, imply racial discrimination. ${ }^{106}$ By contrast, the award in von Pezold and Others indicated that the expropriation was discriminatory because it was based on skin color. ${ }^{107}$ In this context, one of the challenging topics for future arbitral tribunals will be to evaluate to what extent it is appropriate for a host state to deal with historical wrongs based on racial discrimination breaching the non-discrimination requirement of the expropriations provision. ${ }^{108}$

From the aforementioned cases, it can be inferred that land reform can be legally performed if the four requirements for lawful expropriation are met: (1) land reform has to be in conformity with the domestic law and offer the possibility for the expropriated investors to challenge the actin other words, due process; (2) the scope of the land reform has to accomplish the goal to redistribute or reallocate land for righting historical wrongs or improving national food security, among others-in other words, public purpose; (3) the non-discrimination requirement has to be justifiable concerning the public purpose; and (4) compensation has to be given, or at least offered.

Redistributive land reform underlines the importance of non-party rights. In the case of von Pezold and Others $v$. Zimbabwe, four communities of indigenous people and the European Center for Constitutional and Human Rights submitted an amicus curiae petition. The arbitral tribunal

\footnotetext{
${ }^{101}$ These cases are as follows: First, Bernhard von Pezold \& Others v. Zimbabwe-corporations of Bernhard von Pezold \& Others raised separate claims as well, but the separate award is not published. See Border Timbers Ltd., Border Timber Int'l (Private) Ltd. \& Hangani Development \& Co. (Private) Ltd. v. Republic of Zimbabwe, ICSID Case No, ARB/10/25—and both awards following the annulment proceeding ended with the recent Decision on Annulment, November 21, 2018; second, Bernardus Henricus Funnekotter \& Others v. Republic of Zimbabwe, ICSID Case No. ARB/05/06, Award, ICSID Repository (April 22, 2009); and third, Mike Campbell [Pvt] Ltd. \& Others v. Republic of Zimbabwe, No. 2/2007, Decision, Southern African Development Community: Tribunal [S.A.D.C.T.], (Nov. 28, 2008).

${ }^{102}$ Bernardus Henricus Funnekotter \& Others, ICSID Case No. ARB/05/06 at paras. 90, 107.

${ }^{103}$ Bernhard von Pezold \& Others, ICSID Case No. ARB/10/15 at paras. 503, 505.

${ }^{104}$ See Campbell \& Others, No. 2/2007 at paras. 78, 86.

${ }^{105} \mathrm{Id}$. at para. 79.

${ }^{106} I d$. at paras. 93-95.

${ }^{107}$ See Bernhard von Pezold \& Others, ICSID Case No. ARB/10/15.

${ }^{108}$ In any event, in the findings of the case Bernhard von Pezold \& Others v. Zimbabwe, the arbitral tribunal, while dealing with Zimbabwe's defense based on necessity, pointed out that Zimbabwean land reform between Lancaster House Agreement and 2000 was "adequately founded and justifiable," whereas the Fast-Track Land Reform Program (FTLRP) was grounded on political issues and not aimed to repair historical wrongs suffered by indigenous people, and therefore Zimbabwe could not justify the discrimination against land owners in favor of indigenous people. See Bernhard von Pezold \& Others, ICSID Case No. ARB/10/15 at para. 656 .
} 
dismissed the petition based on legitimate doubts on the independence and neutrality of the applicants. This was because the communities' chiefs were found to be related to a person firmly positioned against the claimants, and the communities had customary rights on the claimants' properties. ${ }^{109}$ Moreover, although both the claimants and the arbitral tribunal recognized the interest of indigenous communities in the land over which claimants' have property, the arbitral tribunal held that indigenous communities could unfairly prejudice the claimants-hence, the arbitral tribunal dismissed the petition. ${ }^{110}$ This Procedural Order No. 2 was sharply criticized by the Special Rapporteur on the rights of indigenous people. ${ }^{111}$ In fact, even if the denial of the amicus curiae petition was well-argued on the basis of the applicable law, ${ }^{112}$ it seems unfair for non-dispute third parties to see the faculty to submit their opinions denied. First, they have a significant interest in defending their customary land rights. Second, if customary land rights are disputed, it is difficult to demonstrate a lack of an eventual "unfair prejudice" against one of the parties, or the lack of independence for defending their customary rights over parties' properties.

Indigenous communities could be directly affected by the decision of arbitral tribunals. The arbitral tribunal in that case decided in favor of restitution for the expropriated land to the claimants. Moreover, it is interesting to note that the arbitral tribunal concluded that the land reform in Zimbabwe was not redistributed to indigenous communities solely because of findings from the parties' submissions, witnesses, or testimonies. It is to hope that the interpretation of "unfairly prejudice either party" would not hinder future indigenous communities' submission to be heard because their customary rights on land could be threatened by both host states and investors. Along the same lines-and based on this interpretation of Article 37(2) of the ICSID Arbitration Rules - it is unlikely for indigenous people to be able to participate in submissions as amicus curiae due to their customary land rights that could unfairly prejudice either party.

In conclusion, land reform may be an appropriate measure depending on the host state's needs. Nevertheless, the execution of the latter is undoubtedly delicate, and requires good governance, ${ }^{113}$ which may be lacking in low or middle-income countries. If the host state has sold public land to a foreign investor for large-scale investment in farmland-and at a later time wants to redistribute or reallocate that land due to historical wrongs, or give it to disadvantaged groups-this costly procedure may restrict the host state from acting in the public interest. ${ }^{114}$

\section{Implementing Legislation on Human Rights, Land Tenure Rights, and Environment}

Host states receiving large-scale investments in farmland are usually low or middle-income countries due to their historical background. Currently, these countries are pushed to develop policies to improve social and economic development. The VGGT provide advice to improve land tenure rights and protect human rights and the environment. For instance, the VGGT provide for the protection of customary land tenure rights under municipal law, ${ }^{115}$ and give consultations to indigenous communities or other affected persons when the host state intends to allocate tenure rights. ${ }^{116}$ Additionally, the VGGT provide for the implementation of standards set forth by the

\footnotetext{
${ }^{109}$ Bernhard von Pezold \& Others v. Republic of Zimbabwe, ICSID Case No. ARB/10/15, Procedural Order No. 2, ICSID Repository, paras. 50-56 (Jun. 26, 2012).

${ }^{110} I d$. at para. 62.

${ }^{111}$ See Hum. Rts. Council, supra note 12, at paras. 43, 64.

${ }^{112}$ See International Centre for Settlement of Investment Disputes [ICSID]'s Rules of Procedure for Arbitration Proceedings, art. 37.

${ }^{113}$ VGGT, supra note 98 , at V.

${ }^{114}$ Cotula, supra note 6 , at 41 .

${ }^{115}$ VGGT, supra note 98 , at para. 5.3.

${ }^{116} I d$. at paras. $7.3,8.6,9.2,9.9$.
} 
International Labour Organization (ILO) $)^{117}$ and implement the mandatory assessment on the potential positive or negative impacts of projects involving large-scale investments in farmland. ${ }^{118}$

Here, it is worth stressing that the host state's duty to consult with indigenous peoples before implementing measures that may affect them under Article 19 of the UN Declaration of the rights of indigenous peoples may be elevated as a customary international rule. ${ }^{119}$ Yet, the implementation of these guidelines in national law may affect the farmland investor by increasing the investment costs. These implementations may threaten the FET standard. In this way, if a state establishes that it is required to obtain the informed consent of potentially affected communities, as well as an assessment on the impact of the project before renewing a concession or a lease contract, the investor could raise a FET-based claim. In principle, these host state measures can be elevated as a FET breach if the new regulations are arbitrary, discriminatory, violate the legitimate expectations of the investors, and are implemented without due process. However, a host state will succeed in adopting such regulations with respect to the FET standard if it can justify it with the proportionality of the measure. When an arbitral tribunal performs an analysis of FET standard breaches, it is also important for the tribunal to interpret the standard with the goal of the investment. If the investment treaty promotes sustainable development and the protection of the investment, the regulations mentioned above are unlikely to be held as a breach of the FET standard. ${ }^{120}$

\section{Host State's Defense During ISDS}

ISDS is normally engendered by an investor's claim. Usually host states can contrast these claims only with defenses to achieve the claim's dismissal. Nevertheless, depending on the arbitration provision, a host state can raise counterclaims - and also claims - and can potentially find relief through these avenues. ${ }^{121}$ Nonetheless, in this subsection, the analysis focuses only on potential host states' defenses related to disputes in large-scale investments in farmland.

\section{Right to Regulate}

The right to regulate, as a defense, can be used to justify a host state's measure or a change of the legal framework. Although the pure exercise of the sovereign powers of a host state cannot as such justify a breach of an international obligation. ${ }^{122}$ Of course, this is an undisputed principle when dealing with international obligations and domestic law. Nevertheless, the problem comes when there is a conflict between divergent treaties' obligations. As there is no hierarchy in the sources of international law, peremptory norms excepted, ${ }^{123}$ a host state's right to regulate can turn out to be a successful defense if the latter is a consequence of an international obligation or supported by an international legal instrument. The defense based on the right to regulate can be evaluated within the context of police powers doctrine. Instead of balancing divergent international obligations, arbitral tribunals seem to give some deference to the police powers of the host states, still limiting

\footnotetext{
${ }^{117} I d$. at para. 12.4 .

${ }^{118} I d$. at para. 12.10 .

${ }^{119}$ Grand River Enterprises Six Nations, Ltd., et al. v. United States of America, Arbitration under UNCITRAL Arbitration Rules, Award, para. 210 (Jan. 12, 2011) at https://2009-2017.state.gov/documents/organization/156820.pdf.

${ }^{120}$ See Adel A Hamadi Al Tamini v. Sultanate of Oman, ICSID Case No. ARB/11/33, Award, ICSID Repository, paras. 377-93 (Nov. 3, 2015) (taking into account the Free Trade Agreement (FTA) provision on the protection of the environment in the arbitral tribunal's analysis of minimum standard of treatment).

${ }^{121}$ See Urbaser SA \& Consorcio de Agua Bilbao Bizkaia, Bilbao Biskaia Ur Partzuergoa v. The Argentine Republic, ICSID Case No. ARB/07/26, Award, ICSID Repository, para. 1144 (Dec. 8, 2016).

${ }^{122}$ Article 27 in the VCLT provides that a host state cannot invoke national law to justify a breach of an investment treaty. Vienna Convention on the Law of Treaties, art. 27, May 23, 1969, 1155 U.N.T.S. 331 [hereinafter VCLT]. As put differently in the case of $A D C v$. Hungary, the right to regulate is not unlimited-the boundaries are actually defined by treaties obligations. See ADC Affiliate Ltd. \& ADC \& ADMC Management Ltd. v. The Republic of Hungary, ICSID Case No. ARB/03/16, Award, ICSID Repository, para. 423 (Oct. 2, 2006).

${ }^{123}$ VCLT art. 53.
} 
it by the police powers doctrine. If the state's bona fide conduct aims at protecting a public purpose, it is proportionate and non-discriminatory, then the defense based on the right to regulate has the potential to dismiss the alleged expropriation breach. In the context of large-scale investments in farmland, the police powers doctrine may justify the host state's adoption of provisions inspired by the VGGT - which oblige the investor to respect tenure rights of other beneficiaries, and adopt measures to improve food security and the environment. ${ }^{124}$ In contrast, the police powers doctrine is unlikely to be applicable to justify a land reform without compensation. As land reform implies a direct expropriation of property rights on land, the applicable requirements are those for a lawful expropriation, including the compensation. ${ }^{125}$

The right to regulate as a defense also plays a role in contesting FET claims. Under the FET standard, the predictability and stability of the legal framework are guaranteed together with the investor's legitimate expectations. Still, this principle is to be read in relation with the social and economic peculiarities of the host state. ${ }^{126}$ As most host states receiving large-scale investments in farmland are so-called weak states-where the social and economic standards are not as advanced as in developed countries-a large-scale investor in farmland should not be surprised if the host state starts improving its legal framework to reduce the negative impact of large-scale investment in farmland in order to avoid harm to the environment, to indigenous communities, and threats to human rights. ${ }^{127}$

\section{Investor's Illegal Conduct}

Another host state defense can be grounded on the investor's illegal conduct. As previously indicated, the illegal conduct of the investor $a b$ initio can be recognized as not arbitrable. However, if the investor's conduct is ex post, the arbitral tribunal considers it when assessing the claim's relief. ${ }^{128}$ Nevertheless, as it can be inferred from Philip Morris v. Uruguay-in spite of the case Yukos v. Russia which denied the existence of the unclean hands doctrine as a general principle of law $^{129}$ - that the alleged fraudulent behavior of an investor may be considered by an arbitral tribunal and prevent the investor from raising treaty provisions' claims. ${ }^{130}$ Therefore, while the defense based on the illegal conduct of the investor in obtaining the investment places the investment outside the scope of the investment treaty and excludes jurisdiction, subsequent illegal conduct may also play a role, not only by assessing the claim's relief, but also in defining the admissibility of the single claims.

Regarding an alleged violation of human rights, the award in Urbaser v. Argentina, though dealing with a counterclaim, indicated that corporations could be held to respect human rights as an international obligation. The arbitral tribunal pointed out that under the international investment regime, a corporation is able to hold rights as a subject of international law. Thus, along the same lines, a corporation can also be a subject of international law holding international

\footnotetext{
${ }^{124}$ VGGT, supra note 97 , at para. 12.12 .

${ }^{125}$ On land tenure rights' collision, it is interesting to point out that the Inter-American Court of Human Rights observed that a host state cannot avoid reallocating land to indigenous communities due to the obligations under investment treaty protection of the foreign investor and owner of those lands. As a general matter, a state cannot escape the obligations of the American Convention of Human Rights based on a putative breach of a bilateral treaty, but rather the application of the bilateral treaty shall be compatible with the Convention. See Sawhoyamaxa Indigenous Cmty. v. Paraguay, Inter-Am. Ct. H.R. (ser. C) No.146, para. 140 (Mar. 29, 2006).

${ }^{126}$ Mamidoil Jetoil, ICSID Case No ARB/11/24 at para. 629 ("[T] he heritage of the past as well as the overwhelming necessities of the present and future must be taken in consideration when determining the obligation to provide a stable and transparent legal framework.").

${ }^{127}$ See Philip Morris, ICSID Case No. ARB/10/7 at para. 429.

${ }^{128}$ See supra Section B.I.

${ }^{129} \mathrm{Id}$.

${ }^{130}$ Philip Morris, ICSID Case No. ARB/10/7 at para. 435.
} 
obligations. ${ }^{131}$ Because this reasoning was developed recently in international investment law, it will be interesting to see how this principle is received or adopted by future arbitral tribunals. The emergence of legally binding obligations for corporations under international law is also sustained by the Resolution adopted by the Human Rights Council on the creation of a working group to put together a legally binding instrument on corporations regarding human rights. ${ }^{132}$ In conclusion, if a large-scale investor in farmland violates municipal law or negative international obligations, the host state can use this illegal conduct as a defense or to justify its conduct and obtain a reduced assessment of investor's relief or directly prevent the investor from raising the treaty claim.

\section{State of Necessity}

State of necessity is one of the customary rules that justified a host state's breach of an international obligation. This principle is codified under Article 25 of the International Law Commission (ILC)'s Articles on Responsibility of States for internationally Wrongful Acts. ${ }^{133}$ State of necessity can be invoked to justify a breach of an international obligation due to a severe and imminent peril threatening an essential interest of the state. State of necessity cannot justify a breach of a peremptory norm. ${ }^{134}$ Under international investment law, the host state's defense based on the state of necessity was used mostly by Argentina in defending its conduct as a result of the 2001-2002 financial crisis. ${ }^{135}$ Even though arbitral tribunals treated Argentina's state of necessitybased defense in different ways, it can be said that they all admitted the state of necessitybased defense was a principle of international customary law. ${ }^{136}$

In cases dealing with Zimbabwean land reform, the host state also invoked the state of necessity. In both cases, the arbitral tribunals rejected the defense. While in Funnekotter and Others $v$. Zimbabwe, the arbitral tribunal rapidly rejected the defense, in von Pezold and Others $v$. Zimbabwe, the arbitral tribunal analyzed in detail the state of necessity requirements under Article 25 on State's Responsibility before rejecting it as unconvincing. On the one hand, in Funnekotter and Others v. Zimbabwe, Zimbabwe invoked the state of necessity to justify its difficulty to control the invasion of farms and the expropriation in the public interest. But as the claim was based on the lack of compensation for the expropriated properties, the arbitral tribunal observed that Zimbabwe could not explain why the state of necessity impeded the host state from calculating and paying compensation. ${ }^{137}$ Apart from that, in von Pezold and Others v. Zimbabwe, the arbitral tribunal carefully analyzed the state of necessity's requirements. Zimbabwe held that FastTrack Land Reform Program (FTLRP)—expropriation without compensation-was justified as a state reaction to the land invasions during 2000 and 2013. Therefore, the investment treaty violation was justified by the state of necessity.

\footnotetext{
${ }^{131}$ Urbaser, ICSID Case No. ARB/07/26 at para. 1194. The arbitral tribunal distinguishes between positive and negative human rights obligations. Positive human rights obligations are directed to the host state and imply a duty for the state to enforce such rights_-but these rights do not raise obligations for third persons. Negative human rights obligations imply a general obligation prohibiting the violation of human rights. This can be elevated as both a public and private international obligation. Id. at para. 1210. Therefore, corporations can hold negative obligations under international investment law. The right to water implies a positive obligation for the state to fulfill the human right norm, whereas the prohibition to violate human rights implies also an investor's obligation to abstain. Even though investors may not be holders of positive human rights obligations, they can indeed be holders of negative human rights obligations.

${ }^{132}$ Hum. Rts. Council, Elaboration of an International Legally Binding Instrument on Transnational Corporations and Other Business Enterprises with Respect to Human Rights, A/HRC/RES/26/9, Resolution (July 14, 2014).

${ }^{133}$ ILC's Draft Articles on Responsibility of States for Internationally Wrongful Acts were adopted by the Commission on 2001 and submitted to the General Assembly. This latter, on December 18, 2013, calls the Secretary-General to invite Governments to submit further comments (A/RES/68/104) for evaluating an eventual adoption of a Convention on State Responsibility.

${ }^{134}$ Responsibility of States for Intentionally Wrongful Acts, U.N., art. 26 (Dec. 12, 2001).

${ }^{135}$ Attila Tanzi, State of Necessity, in Max PlancK EnCyClopedia of Public InTERnational Law, 8 (2013).

${ }^{136}$ Id. at $8-11$.

${ }^{137}$ Bernardus Henricus Funnekotter \& Others, ICSID Case No. ARB/05/06 at para. 106.
} 
Article 25 on State's Responsibility provides:

1. Necessity may not be invoked by a State as a ground for precluding the wrongfulness of an act not in conformity with an international obligation of that State unless the act:

(a) is the only way for the State to safeguard an essential interest against a grave and imminent peril; and

(b) does not seriously impair an essential interest of the State or States towards which the obligation exists, or of the international community as a whole.

2. In any case, necessity may not be invoked by a State as a ground for precluding wrongfulness if:

(a) the international obligation in question excludes the possibility of invoking necessity; or

(b) the State has contributed to the situation of necessity. ${ }^{138}$

Based on this wording, the arbitral tribunal examined the conduct of Zimbabwe in relation to the following requirements: (1) the existence of an essential interest of the state; (2) the existence of a grave and imminent peril; (3) no other means were available; (4) the impairment of the international community as a whole; (5) the exclusion of the state of necessity's defense; and (6) the state's own contribution to the necessity situation. First, the arbitral tribunal indicated that the farm invasions were not a threat to the essential interest of the state, but instead to the survival of the incumbent government. ${ }^{139}$ Second, the arbitral tribunal observes that the uprising movement occupying the land was not a grave and imminent peril, because it was not a threat to the state, but more to the government. Moreover, the economic threat increased only after the implementation of the FTLRP because the foreign direct investments were diminished. ${ }^{140}$ Third, the adoption of the FTLRP was not the only means available to contrast the land invasions. Also, the arbitral tribunal pointed out that the government decided not to act against the occupiers and instructed the police not to act. Furthermore, according to the findings of the tribunal, President Mugabe encouraged the occupiers. Therefore, the arbitral tribunal concluded that the FTLRP was not the only method. ${ }^{141}$ Fourth, while the arbitral tribunal was not unsympathetic to the state performing positive discrimination to correct colonial wrongs, the Zimbabwean land reform was based on racial discrimination and FTLRP cannot be elevated as positive discrimination. Additionally, the land reform from the Lancaster House Agreement until 2000 was legitimate because the expropriation had been provided with compensation, and the land had actually been redistributed. By contrast, the FTLRP was pushed as a result of the political pressure felt by the government from occupiers who were led by strong prejudice and racial discriminationnotwithstanding that the claimants invested in the Republic of Zimbabwe and not during the Rhodesian era. Because the government could not justify the racial discrimination of foreign landowners in favor of indigenous communities, it breached its erga omnes obligation and impaired the international community as a whole. ${ }^{142}$ Fifth, the investment treaty provision did not prevent the respondent from invoking the state of necessity. ${ }^{143}$ Finally, the arbitral tribunal observed that Zimbabwe was the first actor in its economic decline and acted as an instigator of the situation that gave rise to the alleged imminent peril. In conclusion, Zimbabwe could not invoke the state of necessity to justify the investment treaty's breaches legally. Even though the arbitral tribunal conducted a careful analysis of the requirements to invoke the state of necessity, the latter would have

\footnotetext{
${ }^{138}$ ILC's Draft Articles on Responsibility of State for Internationally Wrongful Acts, supra note 133.

${ }^{139}$ Bernhard von Pezold \& Others, ICSID Case No. ARB/10/15 at paras. 626-32.

${ }^{140} I d$. at paras. $633-37$.

${ }^{141} I d$. at paras. $638-46$.

${ }^{142} I d$. at paras. $647-57$.

${ }^{143} I d$. at paras. $658-59$.
} 
been more accurate if the indigenous communities interested in the reform could have submitted their opinion on the merits, especially by evaluating the discriminatory feature of the FTLRP.

In conclusion, the state of necessity can be successfully invoked if the investment treaty does not exclude its application and if the aforementioned strict requirements are fulfilled. As a general matter, land reform is, in principle, a planned government policy aiming at achieving sustainable development and not a reaction to a grave and imminent peril. Thus, the state of necessity's defense may be invoked in a case where the host state interferes with foreign investment to guarantee its national food security in a severe food crisis. In any event, the state of necessity is a very exceptional defense.

\section{Public Interest Clause}

Statistics on investment treaties' ISDS outcomes are sometimes used to refute the idea that arbitral tribunals decide in favor of the host state or vice versa. ${ }^{144}$ These statistics are, however, based on the publicly known awards. For example, in 2015, of the fifty-one decisions, only thirty-one were in the public domain. Out of these thirty-one decisions, the majority were decided in favor of the host state on jurisdiction, while on legal merits the majority was decided in favor of the investor. ${ }^{145}$ Even though these statistics may serve as evidence to evaluate the success chances for an investor to challenge a host state's measure, they also show that the main conflicts arise between the private interests of the investor and the public interests of the state. Still, it may be that the host state does not act to protect the public interest, or that, through their private interest in developing and implementing the investment, investors also contribute to develop and reinforce public interest. It is worth noting that the public interest of the state, in terms of public interest for the people and for the environment, is not only a duty for the host state, but also for the investor. As such, an arbitral tribunal should not only focus on an investor's rights and the host state's obligations, but also on the extent of the dispute and the protection of the affected public interest. It is in this context that proposals of scholars are analyzed to introduce a public interest clause in investment treaties. This clause aims to deny investors protection if they, for example, obtain an investment through corruption or the investment involves human rights violations, ${ }^{146}$ and, to protect and improve food security at the same time. ${ }^{147}$ In the following subsections, the notion of public interest is developed, and a public interest clause is framed and analyzed to evaluate if the introduction of the latter in investment treaties could prevent adverse effects of large-scale investments in farmland.

\section{Defining Public Interest}

As indicated previously, investors enjoy an international right to be protected, and the host state enjoys the right to regulate. Additionally, international investment law was conceived to protect foreign investors while promoting investment flow. Therefore, the protection of the public interest is not a goal of international investment law. Nevertheless, due to the current reform of investment treaties and the previously mentioned adverse impacts that some investments can provoke, greater protection of public interest should be promoted. Defining public interest is not an easy task because it is not absolute and can evolve depending on its historical, traditional, and regional context. Therefore, it is a complex endeavor to precisely and conclusively define the range of this powerful notion.

\footnotetext{
${ }^{144}$ EFILA, supra note 94, at 6-7

${ }^{145}$ United Nations Conference on Trade and Development, IIA Issues Note 2: Investor-State Dispute Settlement: Review of Development in 2015, 6, UNCTAD (June 2016), http://unctad.org/en/PublicationsLibrary/webdiaepcb2016d4_en.pdf.

${ }^{146}$ Christian Häberli, Foreign Direct Investment in Agriculture: Land Grab or Food Security Improvement?, ECON. ANALYsIS INT'L L., 299 (2014).

${ }^{147}$ Häberli \& Smith, supra note 8 , at 221-22.
} 
Kulick points out that public interest has two dimensions. On the one hand, there is the collective dimension, and, on the other hand, there is the individual dimension. Both are equally valuable. ${ }^{148}$ For Kulick, the collective dimension entails purposes benefitting the society as a whole, whereas the individual dimension entails purposes benefitting a minority part of the society or an individual as such. ${ }^{149}$ Public interest is a flexible and open-ended term. Depending on the national needs, host states can define what their public interest goals are. In some investment treaties, public interest is defined in general exception provisions by listing the public interest purpose that has to be protected. ${ }^{150}$ Also, general exception provisions modeled after the General Agreement on Tariffs and Trade (GATT) or the General Agreement on Trade and Services (GATS) provisions entail public interest protection by listing public purposes that cannot be undermined by investments. ${ }^{151}$ Notwithstanding these domestic public interests, there are public interests that could go beyond domestic goals and protect "people and the environment from both the host state and the foreign investors." ${ }^{152}$ It is in this latter level that the public interest clause is framed. Interestingly, arbitral tribunals did not develop a case law practice in which the public interest is explicitly taken into account by solving conflicts between conflicting rights. ${ }^{153}$ Thus, explicitly limiting the protection of investment treaty to only investment in compliance with public interest forces arbitral tribunals to consider the right's collision in the merits stage.

Scholars and Special Rapporteurs dealing with large-scale investment in farmland have indicated that these investments can threaten human rights-specifically land rights of indigenous peoples and small-scale farmers - and also food security and the environment. This threat is also confirmed by soft-law instruments related to largescale investments in farmland that try to introduce international standards to avoid the negative impacts of these investments. ${ }^{154}$

For instance, even though it is mainly focused on the protection of food security, the public interest clause proposed by Häberli and Smith, entails the aforementioned public interests. They propose the following:

\section{Public Interest (Food Security)}

Nothing in this Agreement shall be construed

\section{To prevent a Contracting Party from taking measures necessary}

(1) For the protection of its national and local population's food security as defined by relevant international organizations.

\footnotetext{
${ }^{148}$ Andreas Kulick, Global Public Interest in International InVestment LaW, 151-52 (2012).

${ }^{149} I d$.

${ }^{150}$ See, e.g., Chile-United States Free Trade Agreement, Chile-U.S., Annex 10-D, Expropriation 4(b), Jan 1, 2004 (“Except in rare circumstances, nondiscriminatory regulatory actions by a Party that are designed and applied to protect legitimate public welfare objectives, such as public health, safety, and the environment, do not constitute indirect expropriations.").

${ }^{151}$ Although there are only a few investment treaties providing general exceptions modeled on GATT Article XX or GATS Article XIV (see Andrew Newcombe, Chapter 15: General Exceptions in International Investment Agreements, in SUSTAINABLE Development in World Investment Law, Global Law Series, 357 (Marie-Claire Cordonier et al. eds., 2011)), there is an increasing trend to negotiate them. See United Nations Conference on Trade and Development, World Investment Report 2016: Investor Nationality: Policy Challenges, 114, UNCTAD (2016), http://unctad.org/en/PublicationsLibrary/wir2016_en. pdf.

${ }^{152}$ Jorge E Viñuales, International Investment Law and Natural Resource Governance, INTERNATIONAL CENTRE FOR TRADE AND DEVELOPMENT \& WORLD ECONOMIC FORUM, 8 (Sep. 2015), http://e15initiative.org/wp-content/uploads/2015/07/ Extractive-Vinuales-FINAL1.pdf.

${ }^{153}$ As pointed out by Kulick, arbitral tribunals involved with investment treaties are especially inclined to avoid examining conflicting rights - investors' rights versus the collective's rights-during the merits' argumentations, and prefer to implicitly deal with it by assessing reduced compensation or damages. See Andreas Kulick, Sneaking Through the Backdoor - Reflections on Public Interest in International Investment Arbitration, 29 ARB. INT'L 435 (2013).

${ }^{154}$ See supra Section B.I
} 
(2) For the conservation of exhaustible natural resources, water, and live-stock adversely impacted by the investments carried out by an investor of the other Contracting Party.

(3) For the fulfilment of a Contracting Party's international obligations relating to human rights as defined in relevant international treaties and standards.

(4) For ensuring the enjoyment of all legitimate claims to land by rightful individual or communal landowners.

2. In cases of disputes arising from investment contracts covered by this Agreement, complaints by duly interested stakeholders shall be heard along with the parties to the dispute and on the basis, where relevant, of an independent impact assessment addressing all relevant economic, environmental and social aspects as well as the interests of all participants in the investment project. Findings shall ensure that

(1) Such measures should not be applied in a manner that would constitute a disguised restriction on international trade or investment.

(2) Such measures shall be applied in good faith and in a non-discriminatory manner between national and international investors.

(3) Adequate and fair compensation would be provided to the investors of the other Contracting Party for all actions taken and all investments and payments actually made in full compliance with an investment agreement where it had been concluded by competent and duly authorized local or national authorities. ${ }^{155}$

This public interest clause grants the host state the right to regulate in order to protect food security, the conservation of natural resources such as water, the protection of human rights, as well as the land rights of third parties. The right to regulate is limited to measures that do not constitute a disguised restriction on international investment. They are goodfaith measures that do not discriminate between national and foreign investors, and are accompanied by fair and adequate compensation. Even though this public interest clause can protect public purposes threatened by largescale investments in farmland, it does not provide investor obligations as such. On the contrary, it grants a right to regulate to the host state in the mentioned fields when appropriate. The goal of this Article is to go a step further and evaluate if a public interest clause-conferring international obligation to both the host state and investor-may be better suited to protect a higher public interest in cases where host states and investors are unwilling, or unable, to achieve such objectives. This public interest clause would limit the protection of investments causing adverse effects undermining the public interest.

As pointed out by the Special Rapporteur on the rights of indigenous peoples, investment treaty arbitral tribunals do not apply human rights and indigenous peoples' rights as sources of applicable law. ${ }^{156}$ It is essential to point out that affected indigenous communities cannot be a party or receive relief in international investment law. They can participate only as amicus curiae, with "friendly" submissions to the arbitral tribunal. It is worth emphasizing, however, that affected indigenous communities can find relief for a breach of their rights before a municipal tribunal, or under regional or international mechanisms that protect human rights. Investment law tribunals are, in principle, not suited to admit jurisdiction to parties other than the foreign investor and the host state. Notwithstanding the latter, if an investment treaty provision provides that investments do not affect indigenous peoples' rights, an arbitral tribunal is forced to apply indigenous peoples' rights as sources of applicable law. In light of this, the investor may be more inclined to obtain and implement investments in compliance with indigenous peoples' rights, and the state is keener to adapt its legal framework permitting the investor's implementation of the investment

\footnotetext{
${ }^{155}$ Häberli \& Smith, supra note 8, at 222.

${ }^{156}$ See Hum. Rts. Council, supra note 12, at para. 55.
} 
consistent with indigenous peoples' rights. Because large-scale investments in farmland can have adverse impacts on the public interest, by setting obligations to both investor and host state to act without undermining the public interest, it is possible to reduce phenomena such as land grabbing. It is more suitable to refer to public interest alone without mentioning or listing its content in order to avoid a narrow interpretation of the public interest. Arbitral tribunals interpret provisions of the investment treaties according to the general rules of interpretation under Article 31 VCLT. Therefore, to be adequately applied, the public interest clause is not only to be drafted according to its scope, but it is also important that its goal is endorsed by the object and the scope of the treaty. The title and the preamble of the investment treaty should be written to balance public interest with investors' protections. ${ }^{157}$ As for large-scale investment in farmland, the significant preoccupations are related to human rights, indigenous people, the environment, and food security. As such, the following statement could be introduced in the preamble:

Desiring to promote and protect investments compatible with public interest such as, but not limited to, human rights, indigenous peoples' rights, environmental law, and food security.

\section{Public Interest Clause Standard}

The public interest clause will be framed in this section. To find the best way to draft the clause, it is crucial to define: 1) the international standards related to large-scale investments in farmland;2) the main international obligations of host states and investors; and 3) the extent to which the legality condition provision will affect those standards, and how a general exception related to public interests shall be contained in the public interest clause.

\section{International Standards Preventing Land Grabbing}

Adverse effects of investments related to exploitation and use of land comprise the majority of the Compliance Advisor Ombudsman's (CAO) tasks. The CAO is an independent accountability mechanism that aims to resolve conflicts between communities and corporations that make investments supported by the private sector of the WBG, such as the International Finance Corporation (IFC) and the Multilateral Investment Guarantee Agency (MIGA). It is therefore not surprising that fifty-two percent of eligible complaints before the CAO between 2000-2014 were landrelated claims. ${ }^{158}$ Moreover, evidence of the potentially adverse effects caused by some of the investments were included in the UN Guiding Principles on Business and Human Rights. ${ }^{159}$ These Principles impose a duty on the states to protect against human rights abuses in their territories, and they also make corporations responsible for maintaining human rights. Like the UN Guiding Principles, the VGGT do not provide a direct obligation for corporations or non-state actors, but rather a responsibility to respect human rights and land tenure rights. ${ }^{160}$ The latter implies that non-state actors are not directly bound to human rights obligations, but they have to exercise due diligence in order not to impair human rights and land tenure rights. ${ }^{161}$ Just like the VGGT, the UN Guiding Principles also provide that, in order to exercise their human rights diligence, corporations should identify all adverse human rights impacts resulting from

\footnotetext{
${ }^{157}$ See Saluka Investments $B V$ at 300.

${ }^{158}$ Compliance Advisor Ombudsman, Advisory Series Lessons from CAO Cases: Land, 9 (2015), http://www.caoombudsman.org/howwework/advisor/documents/CAO_AdvisorySeries_LAND.pdf.

${ }^{159}$ Report of the Special Representative of the Secretary-General on the issue of human rights and transnational corporations and other business enterprises, John Ruggie, Guiding Principles on Business and Human Rights: Implementing the United Nations "Protect, Respect, Remedy" Framework, Advanced Edited Version, A/HRC/17/31, 13-14 (Mar. 21, 2011).

${ }^{160}$ VGGT supra note 98 , at para. 3.2.

${ }^{161}$ Jochen von Bernstorff, supra note 5, at 38.
} 
their own business. ${ }^{162}$ A human rights impact assessment can be performed before implementing the investment as well as periodically during the development of the business. ${ }^{163}$ The mentioned soft law instruments dealing directly or indirectly with investments in farmland show that an internationally recommended method to prevent, mitigate, and limit adverse effects on human, environmental, and social rights is to implement a mandatory impact assessment. This assessment should be done, not only before obtaining the investment, but also afterward and periodically. ${ }^{164}$ Even though these impact assessments depend only on corporate goodwill, they could be implemented as mandatory in either national law or international law, if introduced in investment treaties. ${ }^{165}$ To limit the adverse effects of large-scale investments in farmland, the introduction of a mandatory environmental, sustainability, and human rights impact assessment should be considered. ${ }^{166}$ These three impact assessments could prevent environmental harm, human rights violations, and at the same time foster sustainable developmentoriented investments - which would limit human rights violations, environmental harm, and food insecurity.

International standards related to indigenous peoples' rights are to be seen together with their self-determination right as an erga omnes obligation, which constitutes a public interest to be protected. ${ }^{167}$ This last point suggests that indigenous peoples shall enjoy the participatory rights of consultation and consent for measures that could affect their land and natural resources rights. This participatory right was first recognized in the ILO Convention concerning Indigenous and Tribal Peoples in Independent Countries. ${ }^{168}$ Moreover, the General Assembly adopted the UN Declaration of the rights of indigenous peoples in 2007, which is widely accepted, though not binding. ${ }^{169}$ This Declaration proclaims, pursuant to Article 19 and Article 32 para. 2, that representatives of indigenous communities shall be consulted and shall give their consent before

\footnotetext{
${ }^{162}$ See Ruggie, supra note 159 , at principle 17.

${ }^{163} \mathrm{Id}$. at principle 18. The impact assessment is also recommended by the former Special Rapporteur on the right to food pursuant to Principles 7 and 9 of the minimum human rights principles applicable to large-scale land acquisitions or leases. See supra note 2 .

${ }^{164}$ The impact assessment, based on a risk-based due diligence for the adverse impacts of corporation's business, is provided pursuant to the revised OECD Guidelines for Multinational Enterprises (2011). In addition, more guidance is given in the context of the OECD Declaration and Decisions on International Investment and Multinational Enterprises. OECD Guidelines for Multinational Enterprises, II para. 10, 20 (2011). This principle was also adopted in the OECD Due Diligence Guidance for Meaningful Stakeholder Engagement in the Extractive Sector. OECD Economic Outlook Annex Tables, 35-36, Annex A (2017). Moreover, the new RAI Principles (2014) under Principle 10 provide the assessment on potential adverse impacts and recognize a level of due diligence for enterprise by avoiding the infringement on human rights. See Committee on World Food Security, Principles for Responsible Investment in Agriculture and Food Systems, 25 http://www.fao. org/3/a-au866e.pdf.

${ }^{165}$ In this context, the Special Rapporteur on the right of indigenous peoples recommends that investment treaties should implement this corporate responsibility. See Hum. Rts. Council, supra note 12, at para. 98. Developing countries were also called to perform a human rights impact assessment before accepting an investment or by controlling it periodically. To provide them with guidance, the former Special Rapporteur on the right to food issued a series of guiding principles. See Hum. Rts. Council, supra note 2 .

${ }^{166}$ In this context, see Andrew Newcombe, Sustainable Development and Investment Treaty Law, 8 J. WORLD INV. \& TRADE 357, 403 (2007). Moreover, the IISD BIT model entails two provisions on pre- and post-establishment impact assessment obligation. See Howard Mann et. al., IISD Model International Agreement on Investment for Sustainable Development, IISD (2005). The IISD BIT model introduces Article 12 on pre-establishment impact assessment indicating that investors shall perform an environmental and social impact assessment and the decisions based on this assessment are applied under the precautionary principle of Article 15 of the 1992 Rio Declaration on Environment and Development. Id. Also, Article 14 provides investor's post-establishment obligations. Pursuant to Article 15 investors must respect national and international standards of corporate governance provided for the special sector of the related investment. Id.

${ }^{167}$ See Hum. Rts. Council, supra note 12, at para. 18.

${ }^{168}$ International Labour Organization, Convention (No. 169) Concerning Indigenous and Tribal Peoples in Independent Countries, arts. 6, 15, 16, June 27, 1989, U.N.T.S. 1650.

${ }^{169}$ Freiburg, supra note 3, at 523.
} 
adopting measures that may affect them. Even though it is still disputed whether the right to consult indigenous peoples has already acquired the status of customary international law, ${ }^{170}$ this principle was also introduced in the UN Guiding principle under Principle 18, which, at the very least, promotes its consultation. Moreover, the Inter-American Court of Human Rights stressed that largescale investments affecting indigenous peoples' rights entail a duty for the host state to consult the indigenous community and obtain the free, prior, and informed consent on an investment project. ${ }^{171}$ Equally, Principle 2 of the minimum human rights principles applicable to largescale land acquisitions or leases proclaims the same standard. ${ }^{172}$ As suggested by Freiburg, this principle may not only be applied to indigenous peoples but could also be related to other peoples affected by large-scale investments in farmland. ${ }^{173}$ In this context, the free, prior, and informed consent allows considering and protecting the rights of small-scale farmers and disadvantaged groups such as historically discriminated groups or rural farmers.

To preserve the public interest threatened by large-scale investments in farmland, human rights, social, and environmental impact assessments are to be performed before their establishment, but also during their operations. Also, where peoples may be affected in their land rights, the free, prior, and informed consent shall be a prerequisite for establishing such large-scale investments.

\section{Obligations of the Host State and the Investors}

The aforementioned international standards bind neither the host state nor the investor, because they are soft law instruments. Nonetheless, introducing these standards as binding in order to admit the international protection of an investment can lead to an improvement of the state governance-especially where the latter is weak or unwilling to protect and foster some public interests. This suggests that, even if the host state did not transpose the international standards in domestic law, they could be held as mandatory through an investment treaty if an investor or host state wants to raise a claim. Therefore, contracting states should negotiate for these standards to be binding under the investment treaties and that arbitration clauses allow the host state to raise counterclaims against the investor-thus providing a cause of action.

In the award in Hesham v. Indonesia, the arbitral tribunal had to deal with a binding treaty provision on investor's conduct. ${ }^{174}$ The arbitral tribunal found that the investor violated Indonesian laws and went against the public interest (Indonesian financial sector), and as such, was precluded from receiving protection under the investment treaty even though the arbitral tribunal found there was a breach of the FET standard. ${ }^{175}$ As pointed out by Newcombe and Marcoux, this award is somewhat unique because it recognizes that investment treaties can provide binding obligations on investors. ${ }^{176}$ The arbitral tribunal observed that this provision ensured

\footnotetext{
${ }^{170}$ States' duties to consult with indigenous peoples before implementing measures that may affect them (pursuant to Art. 19 of the UN Declaration of the rights of indigenous peoples, https://www.un.org/development/desa/indigenouspeoples/wpcontent/uploads/sites/19/2018/11/UNDRIP_E_web.pdf) may be elevated as a customary international rule. See Grand River Enterprises Six Nations, Ltd., supra note 119, at para. 210 (Jan. 12, 2011).

${ }^{171}$ The case of Saramaka People v Suriname, Inter-Am. Ct. H.R. (ser. C) No. 172, III 134-37 (November 28, 2007).

${ }^{172}$ See Hum. Rts. Council, supra note 2.

${ }^{173}$ Freiburg, supra note 3, at 528-29.

${ }^{174}$ Hesham Talaat M. Al-Warraq v. The Republic of Indonesia, UNCITRAL, Final Award, para. 631 (Dec. 15, 2014).

${ }^{175} \mathrm{Id}$. at paras. 645,648 . The provision entailing the respect of public interest was drafted as follows:

The investor shall be bound by the laws and regulations in force in the host state and shall refrain from all acts that may disturb public order or morals or that may be prejudicial to the public interest. He is also to refrain from exercising restrictive practices and from trying to achieve gains through unlawful means

(Art 9 Agreement on Promotion, Protection and Guarantee of Investments among Member States of the Organization of the Islamic Conference). Id.

${ }^{176}$ Andrew Newcombe \& Jean-Michel Marcoux, Case Comment - Hesham Talaat M. Al-Warraq $v$ The Republic of Indonesia: Imposing International Obligations on Foreign Investors, 30 ICSID REV. ForeIGN INV. L.J. 525, 526 (2015).
} 
compliance with the domestic law of the state for foreign investors. This provision sets forth a positive obligation for the investor to comply with municipal law and respect public order. Therefore, the investor's obligations under municipal law acquire the rank of international obligation. ${ }^{177}$ The authors pointed out that this would be the starting point for a new trend in international investment law, which suggests a switch from the asymmetrical mechanism to a symmetrical one, where both individuals and host states hold international rights and obligations. ${ }^{178}$ They also added that negotiating states can create international obligations to respect municipal law, international human rights, environmental obligations, and sustainability standards by introducing positive obligations in investment treaties. ${ }^{179}$ Therefore, the mentioned internationally accepted standards related to large-scale investments in farmland can be introduced in investment treaties and elevated as binding obligations. ${ }^{180}$

If there is misconduct against the public interest of either the investor or the state, the claimant's claims or respondent's counterclaim shall be treated as inadmissible. For this purpose, the Special Rapporteur on the rights of indigenous people recommended that investment treaties provide for a denial of benefits to investments that exercised an inadequate corporate due diligence in human rights and also caused harm to indigenous peoples. ${ }^{181}$ Even though she advised that arbitral tribunals should not have jurisdiction in such cases, it is somewhat more appropriate to treat the claim as inadmissible - if the investment was not illegal ab initio. Therefore, if the investor's conduct does not respect the municipal law or the international standard and causes serious harm to public interest, the latter cannot be entitled to receive the substantive protections provided under the investment treaty. ${ }^{182}$ However, if the misconduct by the investor infringes international standards but is still in accordance with the law of the host state, a concurring "responsibility" of the host state shall be considered in assessing compensation, damages, or costs. Furthermore, the eventual host state counterclaim should also be dismissed as inadmissible if the host state did not incorporate international standards in its legal framework, or if it prevented the investor from complying with the public interest clause. ${ }^{183}$ Thus, taking into account the investor's and host state's obligations, as well as the ISDS clause, I propose the following public interest clause:

Investors are entitled to raise claims only if their investments comply with municipal law and the internationally accepted standards related to the peculiarity of the investment. Alleged breach of municipal law or the mentioned standards incorporated in municipal law may assert counterclaims.

In the case of an ISDS, this provision gives the arbitral tribunal broad power to evaluate whether the investor demonstrated reasonable due diligence - and it should encourage the host state to transpose internationally accepted standards as mandatory in its municipal law to preserve the

\footnotetext{
${ }^{177}$ Hesham, supra note 174 , at 663 .

${ }^{178}$ Newcombe \& Marcoux, supra note 176, at 532.

${ }^{179} I d$.

${ }^{180}$ Not yet into force, the Investment Agreement for the COMESA Investment Area, art. 13 (2007) provides investor's obligations. Investors must comply with the host state's municipal law for the establishment of the investment and during its development. Also, the dispute settlement clause provides that the host state can base its counterclaims on the unlawful investor conduct. $I d$. at art. 28. The dispute settlement clause in the treaty is of major importance to make more effective the public interest clause, and as such the host state shall be allowed to assert counterclaims based on an alleged violation of the public interest clause. The recommendation of the Special Rapporteur on the rights of indigenous people is to entitle host state to raise counterclaims to find relief for an alleged investors' violation of their human rights obligations. See Hum. Rts. Council, supra note 12 , at para. 92 .

${ }^{181} I d$. at para. 98.

${ }^{182}$ See Newcombe, supra note 166.

${ }^{183}$ In this respect, the friendly submission of amicus curiae can play an important role to identify the illegal conduct of both parties.
} 
public interest as a whole. ${ }^{184}$ This public interest clause shall preclude substantive protection to investors if they breach municipal law or internationally accepted standards, but only if there is an arbitrable claim. Therefore, the investment treaty provided by the public interest clause shall explicitly indicate that a state's consent to arbitration is uniquely given for investments obtained "in accordance with the law"; the language here implying the municipal law. ${ }^{185}$

Thus, a ninety-nine-year land-lease contract concerning a 10,000 ha piece of land in exchange for the exploitation of agribusiness activities will be held as perfectly legal and arbitrable if municipal law does not provide a mandatory impact assessment, consultation, or consent of the affected communities. However, if, under municipal law, the precondition for concluding land-deals contracts-which may include largescale land purchases, landleases, or land-concessionsrequires impact assessments and obtaining the consent of potentially affected groups, an investment devoid of these pre-establishment requirements may be held as not arbitrable. By failing the investment's legality condition, a host state does not consent to arbitration. Therefore, the arbitral tribunal does not have jurisdiction to decide the investors' claims. By contrast, the absence of a pre-establishment impact assessment or consultation and consent of potentially affected groups will, in principle, preclude investors from receiving substantive standards protection. This could then motivate the investor to perform the latter even if municipal law does not require it.

\section{Exceptions}

With the introduction of the public interest clause, the presence of a general exception to grant the host state's right to regulate becomes less important. For instance, the International Institute for Sustainable Development (IISD) BIT model general exception provision under Article 51 provides that investor's substantive protections do not apply if the host state takes measures aimed at the improvement of equality in its territory or to protect disadvantaged persons due to historical discrimination. If these measures or laws comply with the internationally accepted standards, they should not create impairment to investors, as they should already apply those standards because of the public interest clause. According to the previously mentioned research, an exception is provided for direct expropriation. This implies that in the case of a land reform aimed at land reallocation, the expropriation requirements cannot suffer an exception, and, as such, compensation is required-even for the authors of the IISD BIT model. Nonetheless, this also implies that if the remaining substantive standards are allegedly breached, such as the FET, the investor cannot find relief. The application of this kind of general exception is also recommended by the Special Rapporteur on the rights of indigenous peoples, but only in the investment treaty where the right to regulate is not sufficiently protected. ${ }^{186} \mathrm{~A}$ public interest clause, together with the scope of the treaty, should be interpreted as attempting to improve the legal framework and, therefore, implicitly granting the host state's right to regulate. Nevertheless, the public interest clause can also coexist with general exceptions, as long as it does not limit the public interest purposes on limited topics.

\section{Public Interest Clause Application}

Although the public interest clause could create some procedural problems, its farreaching goal is well worth the challenge. The proposed clause gives arbitral tribunals a significant margin of appreciation because it should establish whether a breach of municipal law or internationally

\footnotetext{
${ }^{184}$ This public interest clause is also in line with the suggested UNCTAD approach in framing investment treaties that balance state commitments with investor obligations and promote responsible investments. See United Nations Conference on Trade and Development, Investment Policy Framework for Sustainable development, 77-78 (2015), http:// unctad.org/en/pages/PublicationWebflyer.aspx?publicationid=1437.

${ }^{185}$ See supra Section B.I.

${ }^{186}$ See Hum. Rts. Council, supra note 12 , at para. 89.
} 
accepted standards is sufficiently serious to preclude the substantive treaty protection to an investor. Next, it is necessary to analyze the margin of appreciation for arbitral tribunals.

Because the public interest clause precludes the investors from receiving international protection, the application of this clause should be similar to the reasoning of the award in Hesham v. Indonesia. ${ }^{187}$ The arbitral tribunal applied the unclean hands doctrine, which does not allow the investor to be protected in eventual breaches suffered under the investment treaty. ${ }^{188}$ Even though a former award concluded that the unclean hands doctrine is not a general principle of law, ${ }^{189}$ it is not surprising that in the award in Hesham $v$. Indonesia the arbitral tribunal applied this principle-which is applicable by the binding provision on investor's conduct. The proposed public interest clause is to be seen not only as a treaty provision bestowing obligations upon host states and investors, but it should also be viewed as explicitly establishing the unclean hands doctrine. In addition, the host state is also precluded from raising a counterclaim based on an alleged breach of an internationally accepted standard-as long as it has not transposed the related standard to municipal law, or if it cannot reasonably justify the legal gap.

The application of the proposed public interest clause will have different implications on largescale investments in farmland. This clause can potentially undermine the typical investor's rights while promoting and protecting investments in compliance with human rights, environmental law, and sustainabilityoriented investments. First, traditional substantive standards will be granted to the investor without restriction if the latter complies with the public interest clause. The FET standard shall be analyzed together with the public interest clause. ${ }^{190}$ Second, the FPS standard and the use of land shall be analyzed in context with the investor's obligation to perform an impact assessment and mitigate land tenure conflicts. Third, substantive protection on expropriation shall be granted if the investor complies with the public interest clause. If the investors did not comply with internationally accepted standards related to land rights and land use, they might not be internationally entitled to compensation, even if expropriation is lawful. As can be inferred by customary law and the protection of foreign investors, this failure to comply can be held as a violation of the public interest clause and bar investors from compensation for a direct expropriation-but the unlawful conduct must have caused serious violations of human rights or serious environmental harm. Along these lines, the seriousness of the breach of public interests should be proportional to the interference suffered by the investor. The more the investor acted against the public interest, the lesser the relief if the host state breached a substantive provision. Therefore, the conduct of the investor should not be in direct relation with the challenged measure. If the host state expropriates regardless of the misconduct of the investor, the arbitral tribunal should evaluate the impact of eventual illegal conduct and assess whether compensation is due and to what extent.

The public interest clause can be used as a defense or a counterclaim against the investor's claim. The defenses of the states are strengthened by the public interest clause. In contrast, the counterclaims are limited to the legal framework of the host state. A host state cannot find relief from an investor's breach of internationally accepted standards if the latter was not transposed into the municipal legal framework. The right to regulate and to improve standards beyond the minimum international standards may raise some controversial interpretation issues as underlined in the Philip Morris v. Uruguay award, and the concurring and dissenting opinion of

\footnotetext{
${ }^{187}$ Hesham, supra note 174 , at 645 .

${ }^{188}$ In the case at hand, the arbitral tribunal found that Indonesia breached the FET standard, but with the application of the unclean hands doctrine, the claimant could not pursue its claim and find relief. See id. at paras. 647-48, 654.

${ }^{189}$ See supra Section B.I.

${ }^{190}$ For instance, the presence of stabilization clauses impeding to change the legal framework on matters of public interest purposes will not be applicable or considered under investment treaty because they refrain the host state from complying with the public interest.
} 
arbitrator Born. ${ }^{191}$ Nevertheless, the public interest clause, interpreted together with the scope of the treaty should reserve a regulatory space for the host state to foster and protect investments in compliance with public interest.

In conclusion, the introduction of the public interest clause shall promote the respect for broader public interest. This will help cover areas that are not usually taken into account in the investment treaty or ISDS. The investment treaty reform should be directed to achieve a symmetric mechanism to balance the investor's protection with investor's obligations. It is still to be seen whether this will be achieved with the inclusion of the public interest clause or with the creation of investor's international obligations. This rebalanced mechanism will allow for improvement and promotion in investments in accordance with the public interest. At the same time, it will prevent the adverse effects that some investments can provoke-such as with large-scale investments in farmland. When negotiating an investment treaty's provisions-aside from anchoring the investor's protections within the treaty-the specific public interests' goals should be promoted and indirectly protected, especially if the other contracting party is unwilling or unable to achieve such higher goals.

\section{E. Conclusion}

In this Article, the relation between large-scale investments in farmland and international investment law was evaluated. Notwithstanding the adverse effects that these investments can generate, it is clear that international investment law can have the potential to prevent them, especially in the current era where international investment law is switching from an asymmetrical mechanism to a symmetrical one, while also promoting sustainable development. This reform could take a step forward and conceive this mechanism as not pertaining to host states and investors only, but also read to consider the consequences of investment on minority groups and the environment.

Having analyzed the extent of an investor's protection on expropriation and the regulatory space of the host state under an investment treaty, and also having underlined the potential problems that this dual relationship may cause to third actors or some public values, this Article proposed a public interest clause as an answer to grant due protection to investors and the right to regulate to host states-while not undermining the public interest and preventing the adverse effects of largescale investments in farmland. Such a clause would be introduced in investment treaties aiming not only at the protection and promotion of investor's rights, but also at promoting and protecting investments compatible with public interests.

Therefore, the public interest clause would be accompanied by the proposed drafted preamble's statement. Moreover, after analyzing the internationally accepted standards related to large-scale investments in farmland, this Article concludes that such investments need to be obtained and controlled by performing impact assessments in order to avoid generating adverse impacts on public interests. Also, where investments in farmland may affect people's land rights, the free, prior, and informed consent must be a prerequisite to establishing large-scale investments. In this context, the specific obligations of host states and investors were analyzed. And because the internationally accepted standards concerned both host states and investors, the following public interest clause was proposed:

\footnotetext{
${ }^{191}$ As pointed out by arbitrator Born, depending on the arbitral tribunal interpretation, an alleged breach of a treaty standard dealing with a regulatory measure of the host state may be interpreted considering the "deference doctrine" or the "margin of appreciation doctrine." See Philip Morris, ICSID Case No. ARB/10/7 at paras. 181-91 (Arbitrator Born, concurring in part and dissenting in part). As it can be inferred by this concurring and dissenting opinion, both doctrines recognize the right to regulate inherent in states, however the former is restrictive in judging breach of standard provisions and is more suited to protect investor's rights, whereas the latter is more suited for a broader application and can undermine investor's rights.
} 
Investors are entitled to raise claims only if their investments comply with municipal law and the internationally accepted standards related to the peculiarity of the investment. Alleged breach of municipal law or the mentioned standards incorporated in municipal law may assert counterclaims.

This public interest clause goes beyond domestic goals and protects both people and the environment from the host state and foreign investors. First, this clause explicitly limits the protection of investment treaties only to investments in compliance with the public interest, and by extension obliges arbitral tribunals to clearly consider the rights collision in the merits stage. Second, the proposed public interest clause provides investor positive obligations. Third, the clause makes the investor more inclined to obtain and implement investments in compliance with human rights, indigenous peoples' rights, environmental law, and food security. The host state will also be keener to adapt its legal framework allowing the investor's implementation of the investment consistent with the public interest. This can then improve state governance. Fourth, the clause also concretizes the unclean hands doctrine-like provision, where investors are precluded from raising a claim if their conduct does not comply with municipal law and internationally accepted standards, and host states cannot raise counterclaims based on an alleged breach of these standards if they were not transposed to national law. Finally, this clause introduces a symmetric mechanism. Arbitral tribunals shall interpret this clause by balancing the seriousness of the illegal conduct of the investor with the seriousness of the host state's alleged breach of investment treaty's provisions. This balancing will establish whether one claim or counterclaim is admissible and assess the relief that a claim or counterclaim seeks.

In this Article, the role of the home state was consciously left aside. Nevertheless, home states can also play an important role in promoting the protection of public interests. Home states can, for instance, be asked to control the conduct of their corporations abroad and think of an eventual extraterritorial application for their domestic law. Moreover, even if the proposed public interest clause is not conceived within a mechanism where the host state is allowed to initiate an arbitration as a claimant, this solution can also be studied by considering the existing arbitration rules. In this context, the problem is finding the way in which the consent to arbitration is to be given: Should consent be given by a binding provision in investment contracts or left to the goodwill of the latter? Nevertheless, the first actors that can push towards a switch of international investment law are the leading subjects of international law-with these actors of course being the states. Until states refrain from negotiating balanced investment treaties, international investment law will have difficultly evolving towards the promotion and the protection of sustainabilityoriented investments.

Cite this article: Cometti Z (2020). Possibilities of Limiting the Protection of Large-Scale Investments in Farmland. German Law Journal 21, 1198-1227. https://doi.org/10.1017/glj.2020.68 